Western University

Scholarship@Western

Health and Rehabilitation Sciences Publications

Health and Rehabilitation Sciences Program

2017

\title{
Comparing Views about Evidence in Ontario Public Health Units: A Qualitative Descriptive Study
}

Sara Masood

Western University, smasoo3@uwo.ca

Anita Kothari

Western University, akothari@uwo.ca

Sandra Regan

Western University, sregan4@uwo.ca

Follow this and additional works at: https://ir.lib.uwo.ca/hrspub

Part of the Public Health Commons

Citation of this paper:

Masood, Sara; Kothari, Anita; and Regan, Sandra, "Comparing Views about Evidence in Ontario Public Health Units: A Qualitative Descriptive Study" (2017). Health and Rehabilitation Sciences Publications. 13.

https://ir.lib.uwo.ca/hrspub/13 


\title{
Comparing Views about Evidence in Ontario Public Health Units: A Qualitative Descriptive Study
}

\begin{abstract}
Background: Ways of perceiving evidence by public health managers, practitioners and policy makers is one of the key determinants of evidence uptake. Recent public policy in Ontario requires programs to be based on evidence. Therefore, understanding views about evidence in both practice and policy contexts is important to bridge the research-policy-practice gap in public health. Objective and Methods: This qualitative descriptive study examined understandings about evidence in Ontario public health units by comparing perspectives from managers and frontline staff across six geographically-diverse units. A secondary qualitative content analysis was used to re-analyze transcripts of focus groups from the Renewal of Public Health Systems (RePHS) research project. Results: Similarities and differences were revealed with respect to how public health managers and frontline staff view evidence. Although both managers and frontline staff understand that multiple forms of evidence exist and that these forms must be integrated when making decisions regarding program development and implementation, frontline staff highlighted the role of practice-based evidence. Both groups named tools and processes that were available to assist their decision-making. Frontline staff indicated capacity building as important for supporting evidence use. Both groups noted that leadership could present a challenge to evidence-based programs if not supportive of the evidence-based solution for public health problems. However, the understanding of leadership differed between frontline staff and managers. Conclusion: Findings from this study provide insight into how use of evidence can be promoted and how to better support policy implementation efforts within practice contexts.
\end{abstract}

Key words: Knowledge Translation; Evidence; Public Health Policy; Ontario 


\section{Key Messages}

- "Evidence" is broadly defined in the public health setting.

- Public health managers and staff have different ways of perceiving evidence use when it comes to policy implementation.

- Training on how to use evidence continues to be an important enabler.

- The organization is an important target for interventions via infrastructure to support the use of evidence. 


\section{Introduction}

\section{Ontario's Public Health System: A Call for Renewal}

Many health gains have been linked to public health initiatives implemented in Ontario, Canada. For example, there has been an increase of approximately 30 years in the lifespan of Ontarians compared to the early 1900s (Government of Ontario, 2013); smoking rate in Ontario has decreased from 24.5\% in 2000 to $17.4 \%$ in 2014 (Statistics Canada, 2015); the percentage of students from grades 7-12 consuming alcohol has decreased from 54.9\% in 2011 to $49.5 \%$ in 2013 (Boak et al., 2013); and the number of traffic-related deaths has also dropped significantly (Government of Ontario, 2013). Despite these health gains, many health challenges still exist that need immediate attention. These include: chronic and life-limiting conditions, injuries, physical inactivity, unintentional falls, childhood and adult obesity, high stress, and unhealthy alcohol consumption (Government of Ontario, 2013; Manuel et al., 2012; Ontario Chronic Disease Prevention Alliance, 2014; Statistics Canada, 2015). Moreover, infectious disease outbreaks, such as the Severe Acute Respiratory Syndrome (SARS) in 2003, have identified further areas that require improved public health measures (Naylor et al., 2003). Given the preventable nature of some of these illnesses, diseases and/or injuries, there is still a need for the development and implementation of effective public health programs and services. This will not only contribute to further individual level gains (such as increased life expectancy and decreased prevalence of chronic conditions), but also key system level gains (such as decreased healthcare costs and fewer hospitalizations). Consequently, a call for public health renewal in Ontario was made to meet the specific needs of Ontarians as well as to improve the general functioning of Ontario's public health system (Canadian Institute of Health Research [CIHR], 2003; Capacity Review Committee, 2006; Naylor et al., 2003). 


\section{Ontario Public Health Standards}

Public health is defined formally in Ontario as "the organized efforts of society to prevent illness, disease, and injury through a sustained combination of approaches, including one-on-one health services, health promotion, health protection and healthy public policies" (Government of Ontario, 2013, p. 6). Ontario has thirty-six independent or autonomous public health units (Ministry of Health and Long-Term Care [MOHLTC], 2014). Each public health unit has a board of health that is overseen by the medical officer of health who is accountable for program planning and delivery at the local level (MOHLTC, 2014). Funding for public health is provided by the provincial government as well as the municipal governments (MOHLTC, 2014). The activities of public health are governed by the legislation issued by the Ministry of Health and Long-Term Care (MOHLTC, 2014).

The development of the Ontario Public Health Standards (OPHS) and the incorporated Protocols are widely recognized as an important milestone in public health renewal. The OPHS and Protocols were established by the Ministry of Health and Long-Term Care in 2008 to outline the legislated minimum requirements for each board of health and to provide them guidance for “the assessment, planning, delivery, management, and evaluation of a variety of public health programs and services that address multiple health needs" (MOHLTC, 2016, p. 3). The 2008 OPHS and Protocols replaced the 1997 Mandatory Health Programs and Services as of January 1 2009. The OPHS 2008 were revised slightly in May 2016 (see MOHLTC, 2016).

Figure 1 provides a visual representation of the Ontario Public Health Standards (MOHLTC, 2016, p. 11). The OPHS consists of three foundational components: Principles, Foundational Standard, and Program Standards. The Principles were developed to guide public health activity as well as "to balance local public health needs with the need for common 
outcomes across the public health system" (Public Health Services Hamilton, 2008, p. 4). The four Principles of the OPHS include: Need, Impact, Capacity, and Partnership and Collaboration (MOHLTC, 2016, p. 10). The Foundational Standard describes four key activities and specific requirements concerning these activities that must be carried out by boards of health when organizing public health services and programs in the province, including Population Health Assessment, Surveillance, Research and Knowledge Exchange, and Program Evaluation (MOHLTC, 2016, p. 10; Public Health Services Hamilton, 2008). Finally, Program Standards are provided for five specific core program areas including Chronic Disease and Injuries, Family Health, Infectious Diseases, Environmental Health, and Emergency Preparedness (MOHLTC, 2016, p. 11). Each of the five Program Standards has specific goals, societal outcomes, board of health outcomes, and requirements (MOHLTC, 2016, p. 13). 


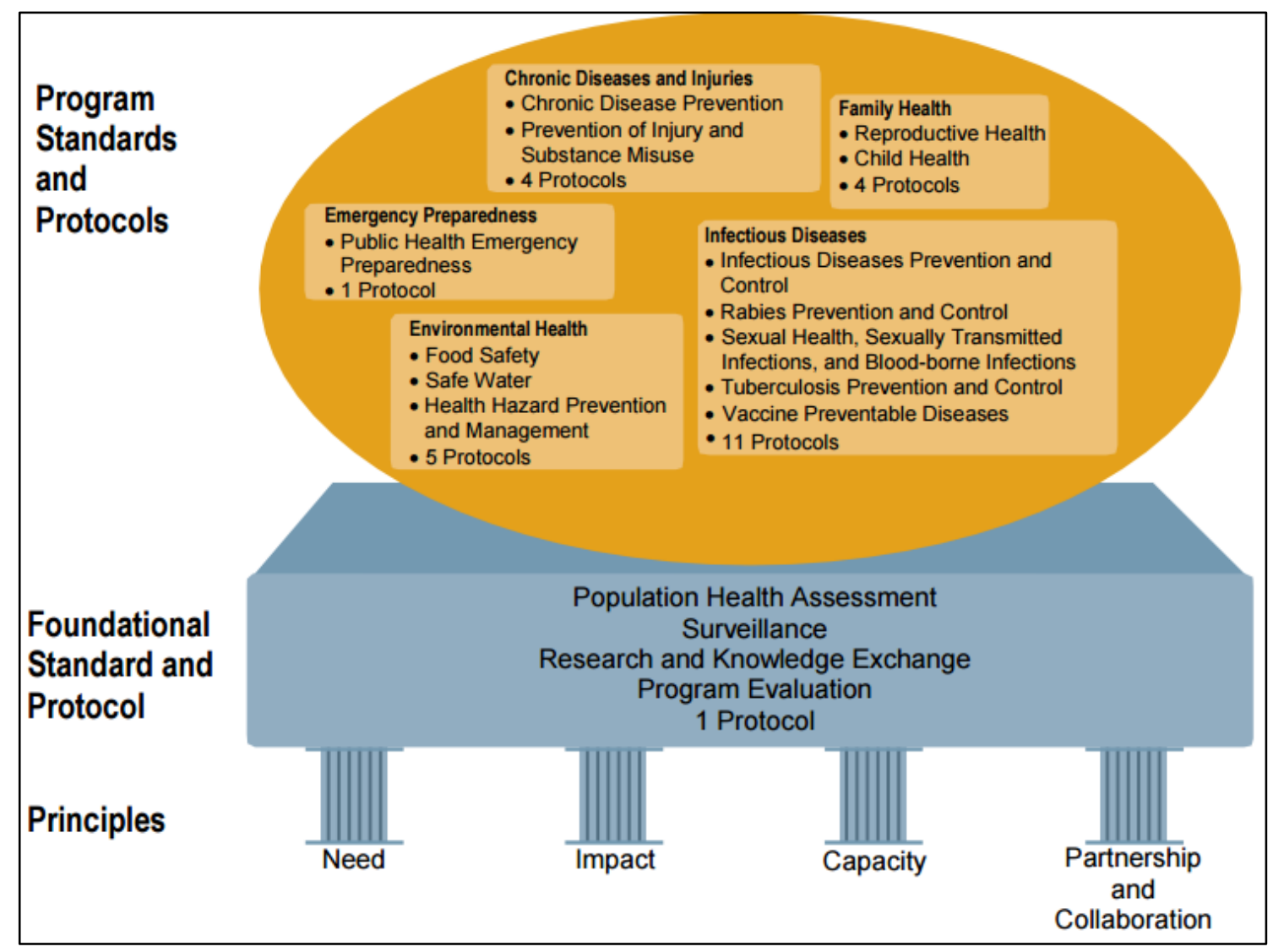

\section{Figure 1: Ontario Public Health Standards (OPHS) Framework}

Source: Ontario Public Health Standards 2008. Revised May 2016, by Ministry of Health and Long-Term Care (MOHLTC), 2016, p. 11. Retrieved from:

www.health.gov.on.ca/en/pro/programs/publichealth/oph_standards/docs/ophs_2008.pdf

One of the key elements of the OPHS, unlike previous guidelines, is the strong focus on the use of available evidence and best practices in developing programs and on the use of evidence-based tools to inform public health practice (MOHLTC, 2016). Thus, the OPHS have the potential to inform public health professionals' use and integration of both explicit knowledge (i.e., knowledge that comes from "articulated theories and empirical studies") and implicit knowledge (i.e., knowledge that comes from the "judgment of individuals with extensive experience in an area") (Bhattacharyya et al., 2009, p. 493). As such, several general resources 
and guidance documents have been produced to support and facilitate the implementation of the OPHS and the incorporated protocols (see MOHLTC, 2015).

\section{The Way Forward}

In order to assess the implementation of the OPHS and to inform the current public health renewal initiatives in Ontario, there is an important need to understand factors influencing the process of evidence uptake within public health units. Previous studies have explored different aspects of evidence and its use in public health, with key topic areas being types of evidence used in public health practice, barriers and facilitators affecting the use of evidence, and a range of effective strategies to promote evidence use.

Most studies about evidence use have focused on research evidence, but scholars have highlighted that there are two main types of evidence: explicit knowledge and implicit knowledge (Bhattacharyya et al., 2009; Greenhalgh and Wieringa, 2011). Within the two main types of evidence are several sub-types, indicating the diversity and complexity of the concept of evidence (Glasgow and Emmons, 2007; Kothari et al., 2015). A number of studies have shown that an integration of tacit and explicit knowledge is often carried out within the public health context (Higgins et al., 2011; Kothari et al., 2012; Meagher-Stewart et al., 2012; YousefiNooraei et al., 2014), suggesting that studies focused on understanding the utilization of evidence need to employ a broad definition of evidence that moves beyond just research findings.

Studies focused on the determinants of evidence use discuss six types of barriers and facilitators. This includes factors related to aspects of: (i) the individuals involved in decision making (Armstrong et al., 2014; Ellen et al., 2014; Grol and Grimshaw, 2003; Huckel Schneider et al., 2014; LaRocca et al., 2012; Orton et al., 2011; Rosella et al., 2013; Zardo and Collie, 2014); (ii) the organization/agency within which decisions are made (Armstrong et al., 2014; 
Bhattacharyya et al., 2009; Ellen et al., 2013; LaRocca et al., 2012; Laws et al., 2013; Milat et al., 2014; Rosella et al., 2013).; (iii) the research being considered for uptake (Francis et al., 2015; Glasgow and Emmons, 2007; Langley and Denis, 2011; Laws et al., 2013; Wathen et al., 2011; Zardo and Collie, 2014); (iv) the social networks and relationships with relevant stakeholders (Armstrong et al., 2014; Ellen et al., 2013; Ellen et al., 2014; Francis et al., 2015; Huckel Schneider et al., 2014; Wathen et al., 2011); (v) the economic climate (Bhattacharyya et al., 2009; Ellen et al., 2014; Francis et al., 2015; LaRocca et al., 2012; Laws et al., 2013); and (vi) the political environment related to a given public health issue (Armstrong et al., 2014; Grol and Grimshaw, 2003; Huckel Schneider et al., 2014; Laws et al., 2013). Thus, evidence use is a multilevel, complex process that includes some determinants that are amenable to change (e.g., attitudes, skills, infrastructure) and other determinants that are unlikely to change (e.g., larger political system, time constraints).

Recent systematic reviews in this area point towards three KT strategies that can help promote evidence use in public health (LaRocca et al., 2012; Masood et al., 2017; Mitton et al., 2007; Perrier et al., 2011). This includes (i) knowledge brokering (Dobbins et al., 2009; LaRocca et al., 2012; Masood et al., 2017, Mitton et al., 2007; Perrier et al., 2011; van Kammen et al., 2006); (ii) partnerships and networks (Kothari et al., 2011; LaRocca et al., 2012; Masood et al., 2017; Mitton et al., 2007); and (iii) evidence syntheses (Lavis et al., 2004; Masood et al., 2017; Mitton et al., 2007; Perrier et al., 2011; Thomson, 2013). Each of these three strategies fosters interactions between distinct groups involved in making decisions regarding public health programs and services, which can subsequently help to bridge evidence-practice-policy gap in different ways. 
One important aspect of evidence use that is not as widely studied is to understand how public health managers and frontline staff differ in their views about evidence, related barriers and facilitators, and how these differences in views about evidence might (or might not) support policy and organizational implementation efforts in the health units. Ways of perceiving evidence by different health care managers, practitioners, and decision makers is reported to be one of the key factors influencing the process of evidence uptake (Kyratsis et al., 2014). Given that professional groups come from a diverse range of educational backgrounds, belong to a variety of different value systems, and perform a set of specific professional roles, their ways of perceiving evidence are likely to be distinct (Langley and Denis, 2011). However, empirical evidence on how different health care managers, practitioners, and decision makers make sense of evidence is sparse, especially in the context of Ontario's public health system and since the implementation of the OPHS. Therefore, this research study sought to address this important gap in knowledge about evidence and public health.

\section{Objective and Research Question}

The primary objective guiding this study was to understand views about evidence in Ontario public health units. This objective was accomplished by exploring the research question: What are the similarities and differences in the views about evidence held by public health managers and frontline staff in Ontario?

\section{Methods}

\section{Study Design}

This study used a qualitative description design, as described by Sandelowski (2000), and qualitative content analysis as a method of analysis. Qualitative descriptive design allows one to capture an in-depth description or summary of a phenomenon of interest about which we know 
little, and is especially useful when there is a need for straightforward answers to questions that are relevant to practice or policy (Sandelowski, 2000). It is typically based on naturalistic inquiry (Sandelowski, 2000) which supports the belief that the phenomenon of interest must be studied in its natural state where possible (Lincoln and Guba, 1985). The interpretations in a qualitative descriptive study are "data-near", meaning the interpretations are achieved by staying close to explicit statements in the data and avoiding inferring extensively (Sandelowski, 2010, p. 79).

Qualitative content analysis method was specifically used to conduct a secondary analysis of focus group data. Secondary analysis involves applying a new research question to a pre-existing data sample that was collected for another study or purpose (Heaton, 2008). Secondary analysis allows one to generate new knowledge about a phenomenon by exploring a different research question. Also, secondary analysis provides an opportunity to focus on the data analysis phase since sampling and data collection have been carried already (Szabo and Strang, 1997).

The RATS reporting guideline for qualitative studies was followed to guide accurate and complete reporting of all key aspects of this research study, and to support a rigorous research process (see: http://old.biomedcentral.com/authors/rats) (Clark, 2003; Dixon-Woods et al., 2004; Eccles et al., 2012).

\section{Data Source}

The pre-existing qualitative data used in this study were collected during Phase I (2010) of the Renewal of Public Health Systems (RePHS) research project (RePHS, 2010; see http://www.uvic.ca/research/groups/cphfri/projects/currentprojects/rephs/index.php). The prime aim of the multi-phase RePHS research project was to understand the implementation and the impact of the BC Core Public Health Functions framework and the Ontario Public Health 
Standards using complex adaptive systems theory (RePHS, 2010). This aim was achieved through a case study design employing different data collection strategies, with cases being two core public health programs (i.e., Chronic Disease Prevention/Healthy Living (CDP) and Sexually Transmitted Infection Prevention (STIP)) (RePHS, 2010). The research questions of the primary RePHS study included: (1) "What are the processes of the public health standards and core functions of implementation for two core public health programs in $\mathrm{BC}$ and Ontario, and how do contextual variations within and between each province affect the implementation?"; and (2) "What are the impacts and outcomes of the two core programs and how does variation in context and process of implementation affect these?" (RePHS, 2010).

\section{Sampling}

Purposeful sampling techniques are typically employed in qualitative descriptive studies (Sandelowski, 2000). This study specifically used maximum variation sampling, which involved purposefully selecting or sampling information-rich cases to capture a range of views around evidence (Patton, 1990). Given that procedures of STIP are mostly directed (i.e., guided by medical guidelines), we selected our sample to focus on discussions about CDP where there is greater leeway to plan and implement programs. Hence, all focus group data from Phase I of RePHS study related to the CDP program area (limited to physical activity, healthy eating, and tobacco control programs in the original RePHS study) were used. Specifically, this included 12 focus group transcripts consisting of 6 focus groups with managers $(n=24)$ and 6 focus groups with frontline staff $(n=40)$ involved in CDP programs at six rural and urban public health units across Ontario. Including data from various public health units across Ontario and from both managers and frontline staff allowed variations due to differences in geographic location and contextual factors as well as for diverse perspectives to be expressed. The 64 focus group 
participants were from diverse disciplines (see Table 1). These participants had varying levels of experience with regards to their level of position and length of time spent in their respective public health units.

Table 1: Background of study participants $(n=64)$

\begin{tabular}{|l|l|}
\hline Discipline/Title & $\begin{array}{l}\text { Number of } \\
\text { Participants (n) }\end{array}$ \\
\hline Public health nurse & 21 \\
\hline Health promoter & 13 \\
\hline Public health dietician & 8 \\
\hline Public health nutritionist & 7 \\
\hline Public health nutritionist/dietician & 3 \\
\hline Community/chronic health nurse & 2 \\
\hline Health promotion consultant & 2 \\
\hline Health promotion officer & 2 \\
\hline Youth engagement coordinator & 1 \\
\hline Public health inspector & 1 \\
\hline Gerontologist & 1 \\
\hline Project officer & 1 \\
\hline Project specialist & 1 \\
\hline Policy and planning specialist & 1 \\
\hline
\end{tabular}

\section{Data Collection}

Focus groups in the primary RePHS study were conducted by the study co-investigators and were generally 60-90 minutes in length. During the focus group discussions, participants were asked to share their views about several topics relating to the introduction of the 2008 OPHS including questions about: participant background, changes in activities since the introduction of the OPHS; evidence; planning; leadership; implementation; evaluation; and partnerships. All questions were open-ended. Focus groups were audio recorded and recordings were then transcribed verbatim by a professional transcriptionist. For the purpose of this study, however, only responses specific to the evidence and evidence use questions were reviewed and analysed (see Table 2 for a detailed list of questions). 
Table 2: RePHS Phase I focus group questions regarding evidence for Ontario managers and frontline staff

\begin{tabular}{|c|c|}
\hline Questions for Managers & Questions for Frontline Staff \\
\hline $\begin{array}{l}\text { 1. In general, what informs or guides your practice? } \\
\text { (E.g., literature, observing/talking to peers/experts) } \\
\text { a. What has the most influence in guiding your } \\
\text { practice? } \\
\text { 2. What does the word evidence mean to you? } \\
\text { a. What constitutes evidence for you? } \\
\text { 3. What evidence or information was used to inform the } \\
\text { development of the CDP/STIP program activities as they } \\
\text { relate to the OPHS? } \\
\text { 4. What is the process for applying evidence in program } \\
\text { development? } \\
\text { a. How are the OPHS, protocols, and guidance } \\
\text { documents used? } \\
\text { b. At what level(s) are decisions made in terms of what } \\
\text { evidence is used? } \\
\text { (E.g., who decides what evidence is used?) } \\
\text { 5. What influences how and what evidence is used? } \\
\text { 6. Do you have an opinion on their use? } \\
\text { 7. Has there been an effort to create/develop provincial } \\
\text { evidence as a result of public health renewal? } \\
\text { 8. Are there barriers to implementing evidence? }\end{array}$ & $\begin{array}{l}\text { 1. In general, what informs or guides your practice? } \\
\text { (E.g., literature, observing/talking to peers/experts) } \\
\text { 2. What does the word evidence mean to you? } \\
\text { a. What constitutes evidence for you? } \\
\text { 3. What evidence/strategies do you use to guide/inform } \\
\text { your practice as they/it relate(s) to the OPHS? } \\
\text { 4. What kinds of mechanisms are in place for you to } \\
\text { foster the use of evidence if any? } \\
\text { 5. How do you think evidence is used in relation to the } \\
\text { CDP/STIP activities? } \\
\text { 6. Do you encounter barriers regarding implementing } \\
\text { evidence in your practice? }\end{array}$ \\
\hline
\end{tabular}




\section{Data Management and Analysis}

The qualitative content analysis method used was the one articulated by Graneheim and Lundman (2004), and described by Hsieh and Shannon (2005) as a conventional approach involving a multi-step process (Graneheim and Lundman, 2004; Hsieh and Shannon, 2005). All focus group transcripts were imported into NVivo 10, a qualitative data analysis software. A meaning unit, defined as "the constellation of words or statements that relate to the same central meaning" (Graneheim and Lundman, 2004, p. 106), was sentences (or sometimes phrases) related to the evidence and evidence use questions. The first step of the data analysis was familiarization, which involved reading through all transcripts multiple times to become immersed in the data. In this way the characteristics of the participants, the content of the transcripts, and the context were understood (Hsieh and Shannon, 2005).

The second step of the data analysis was creating codes (Graneheim and Lundman, 2004; Hsieh and Shannon, 2005) using open-coding (Elo and Kyngäs, 2008). Open-coding involved reading through the transcripts word by word and then labelling (highlighting) chunks of data "that appear to capture key thoughts or concepts" (Hsieh and Shannon, 2005, p. 1279). A priori focus group questions were used to organize how coding began, but codes under that were inductively derived from the data (i.e., predetermined codes were not used). Re-coding of all transcripts was done when new codes emerged from the data or when there was a need to combine the existing codes (Elo and Kyngäs, 2008).

The third step of the analysis was to organize the related and linked codes into smaller, manageable content categories (Graneheim and Lundman, 2004; Hsieh and Shannon, 2005). This specific step involved step-by-step formulation of inductive categories by which the data could be examined and referenced (Mayring, 2000; Morgan, 1993). All categories were derived from 
the data itself (i.e., from the issues raised by participants and the words or concepts that recurred in the data) to ensure that participants' views were adequately captured and that the categories were specifically catered to the data being analyzed (Morgan, 1993; Pope et al., 2000). Category development helped reveal what overarching patterns exist given the different contexts that underlie the data. This research study used the term 'subthemes' to refer to categories.

The final step of the data analysis process was "to link the underlying meanings together in categories" by creating themes (Graneheim and Lundman, 2004, p. 107). A theme is defined as "a recurring regularity developed within categories or cutting across categories" (Polit and Hungler, 1999). The process of creating themes was related to latent content analysis which focused on analyzing the relationships existing in the textual material and the underlying meanings of the content (Graneheim and Lundman, 2004; Hsieh and Shannon, 2005). As such, theme development helped reveal how and why certain patterns existed given the different contexts that underlie the data (Graneheim and Lundman, 2004).

\section{Trustworthiness}

To ensure credibility, purposeful sampling was used to select all relevant CDP focus group transcripts from Phase I of the primary RePHS study. Moreover, the codes, categories, and themes generated from the analysis of data were reviewed by and discussed amongst all authors, two of whom (AK and SR) are part of the primary RePHS research team and have experience in both public health research and qualitative research methods. Furthermore, credibility of findings

was demonstrated by including example quotations when presenting each theme, as suggested by Graneheim and Lundman (2004).

To ensure dependability during the data analysis process, rigorous reflexivity and selfawareness were employed throughout the research work by keeping detailed personal notes 
documenting how decisions were reached and by being conscious of prior knowledge (Tracy, 2010). These notes were reviewed regularly. In addition, all key aspects of this research study were accurately and completely reported to enable external researchers to replicate this study process. To facilitate transferability, a rich description of research findings, culture, and context was provided.

\section{Ethical Considerations}

McMaster Research Ethics Board provided ethics approval for the primary RePHS study. An additional ethics approval from Western's Research Ethics Board was not required due to the nature of this research study.

\section{Results}

Five major categories emerged from the analysis: 1) meanings of evidence, 2) evidence in practice, 3) process for applying evidence, 4) facilitators of evidence use, and lastly 5) barriers to implementing evidence. In the following sections, the comparisons of managers and frontline staff views are presented for each of the five categories. Illustrative quotes are used throughout to demonstrate findings in participants' own words. Quotes are attributed to particular participants using unique identifiers consisting of three parts: the first part identifies participant as either a manager (M) or a frontline staff (F); the second part (letters A-F) identify the six public health units; and the third part identifies participant number.

\section{Meanings of Evidence}

Table 3 provides a summary of the responses received from public health managers and frontline staff when asked what the term evidence means to them. The responses demonstrate the diversity in the meanings of evidence. 
Table 3: Summary of the different meanings of evidence that emerged from the data

\begin{tabular}{|c|c|c|}
\hline & Managers & Frontline Staff \\
\hline \multirow{5}{*}{ Similar Views } & $\begin{array}{l}\text { "something with impact" } \\
\text { (Participant MA1) }\end{array}$ & $\begin{array}{l}\text { "has some measurable impact" (Participant } \\
\text { FD6) }\end{array}$ \\
\hline & $\begin{array}{l}\text { "numbers driven, it's very } \\
\text { prescriptive" (Participant MA2) }\end{array}$ & $\begin{array}{l}\text { "is a quantitative thing. You do this with } \\
\text { somebody and this will happen" } \\
\text { (Participant FE2) }\end{array}$ \\
\hline & $\begin{array}{l}\text { "how do you know it works" } \\
\text { (Participant MD1) }\end{array}$ & $\begin{array}{l}\text { "proof that something is effective or isn't } \\
\text { effective, or this is the way to go or not to } \\
\text { go" (Participant FC3) }\end{array}$ \\
\hline & $\begin{array}{l}\text { "research that has been done on a } \\
\text { specific strategy, activity, } \\
\text { approach" (Participant MB1) }\end{array}$ & $\begin{array}{l}\text { "stuff backed up by strong research } \\
\text { literature" (Participant FC4) } \\
\text { "something you can trust, something that's } \\
\text { kind of research-based" (Participant FA7) } \\
\text { "evaluated, proven, researched. Theory- } \\
\text { based" (Participant FB2) }\end{array}$ \\
\hline & $\begin{array}{l}\text { "a combination of the academic } \\
\text { literature, grey literature, and the } \\
\text { community" (Participant MC6) }\end{array}$ & $\begin{array}{l}\text { "best currently available information or } \\
\text { knowledge and demonstrates what works" } \\
\text { (Participant FA4) }\end{array}$ \\
\hline \multirow{4}{*}{ Different Views } & $\begin{array}{l}\text { "not re-inventing the wheel" } \\
\text { (Participant MA1) }\end{array}$ & $\begin{array}{l}\text { "a reason for action to make a move or to } \\
\text { get the ball rolling" (Participant FA7) }\end{array}$ \\
\hline & $\begin{array}{l}\text { "something tangible" (Participant } \\
\text { MA2) }\end{array}$ & $\begin{array}{l}\text { "justification for what you're doing" } \\
\text { (Participant FB6) }\end{array}$ \\
\hline & & "that-makes-sense" (Participant FA2) \\
\hline & & $\begin{array}{l}\text { "[sometimes] almost a barrier" (Participant } \\
\text { FC3) }\end{array}$ \\
\hline
\end{tabular}

Note: Similarities are highlighted in blue.

The major theme emerging from manager and frontline staff responses to the question "what constitutes evidence for you" was that there are multiple forms of evidence, and that all of these forms must be considered and integrated when making decisions regarding CDP program development and implementation. As one manager described it:

I think certainly the message that we communicate quite strongly is that there are multiple forms of evidence, and that we need to assess and evaluate all of them and think about the role that each one of them plays in our decision-making. So that is literature, 
quantitative/qualitative literature. It is anecdotal from staff, what they see in the field, it is community partners and key informants, what they perceive as, as need or best practice, and political context. Community context. So all of those things together, I think, really need to be considered and integrated into those decisions. (Participant ME1).

Similarly, a frontline staff spoke to this theme quite clearly with an example:

It would look like feedback from your teachers, from your students, the parents, what they tell us, or what the teachings are hearing the students say about certain issues. Or what they are observing in the classroom, because we can't be there all the time. I think there has to be a good marriage between the anecdotal and the hard evidence. (Participant FE3).

While this theme was prominent, an additional insight that emerged from the focus groups with managers and frontline staff was that the perception of what constitutes evidence in public health practice has only recently started to shift from being more exclusive (to research findings) to being more inclusive (to other forms of evidence). Managers attributed this shift in perception partly to the OPHS due to its greater emphasis on evidence use, its support to increase resource allocation towards identifying and gathering relevant local evidence, and its expectations of health units to contribute to the evidence base and share with other health units. Frontline staff pointed out that there has been a shift in the understanding of research evidence by public health professionals, including both frontline staff and their managers. They indicate that previously, research was considered something more quantitative-focused with an emphasis on capturing breadth through population representation, but recently the value of qualitative work and its ability to capture the depth of a given phenomenon has also been realized. 


\section{Evidence in Practice}

Table 4 outlines the major forms of evidence that managers and frontline staff use to inform or guide their practice with respect to CDP activities. The forms of evidence emerging from the data can be categorized into four main thematic areas: 1) local, 2) expert, 3) research, and 4) experiential evidence. ${ }^{1}$ These evidence forms involved different sources of explicit and tacit knowledge. Generally, the forms of evidence considered by public health managers and frontline staff to inform or guide their practice is context specific and "really depends on the topic area" (Participant MC3).

Public health managers and frontline staff indicated that they gather as much relevant evidence as possible given their capacity, time, and funding. However, what evidence actually gets used in practice is greatly influenced by many factors. The main factors are political pressure as well as public demands for the use of evidence. As explained by one manager:

I'd like us to think that we can influence the politicians with our evidence but rather I think it's kind of the other way - they tell us. And we seem to have a fairly quiet voice around that...so in terms of how we do our planning it is you know the palatability from sort of the public, the politicians, takes much greater weight in the overall scheme of things than real hard evidence in terms of what we should be doing. (Participant MF6).

Likewise, a frontline staff explains this situation in a similar manner:

We may say, oh the evidence is saying this, the research is saying this, the community assessment is saying this, but a councillor may have a particular interest area and say no, but you are doing helmets at skateboarding parks, for example. And then that's how our path may be chosen and that's the reality of a political city. (Participant FB2). 
Other factors influencing what evidence is used in practice according to some managers include: individual bias (e.g., staff strategically using only evidence that supports their opinions or actions); and whether the issue to be addressed is cross-cutting (e.g., the number of factors and sectors associated with the issue). According to frontline staff, on the other hand, other factors influencing what evidence is used in practice included the support (or lack of support) of city councillors and community organizations. 
Table 4: Evidence identified by managers and frontline staff as guiding their practice

\begin{tabular}{|c|c|c|c|c|}
\hline & \multirow[t]{2}{*}{ Themes } & \multicolumn{2}{|c|}{ Subthemes } & \multirow[t]{2}{*}{ Example Quotes } \\
\hline & & Managers & Frontline Staff & \\
\hline \multirow{3}{*}{$\begin{array}{l}\text { Similar } \\
\text { Views }\end{array}$} & \multirow[t]{2}{*}{ Local } & $\begin{array}{l}\text { Community consultations } \\
\text { and assessments }\end{array}$ & $\begin{array}{l}\text { Community consultation } \\
\text { and assessments }\end{array}$ & $\begin{array}{l}\text { "So when we're program planning, we have to } \\
\text { make sure that any program is going to be accepted } \\
\text { and actually it's something that the community } \\
\text { wants because otherwise you might as well be } \\
\text { talking to the wall. So we do look at what is the } \\
\text { important pieces that are coming from the } \\
\text { community." (Participant MC5) } \\
\text { "I'd say for us it's the needs of the community ... } \\
\text { We hear from them what we ... we have a pulse on } \\
\text { what is going on at the current time and you know } \\
\text { either provide resources to help or look at } \\
\text { programming and what our capacity is to fulfil that } \\
\text { need, so." (Participant FC3) }\end{array}$ \\
\hline & & $\begin{array}{l}\text { Epidemiological data / } \\
\text { Health status reports }\end{array}$ & $\begin{array}{l}\text { Epidemiological data / } \\
\text { Health status reports }\end{array}$ & $\begin{array}{l}\text { "We look at our epidemiology pieces with our you } \\
\text { know health-specific data with our Epi Department } \\
\text { and most, I think, most programs are going through } \\
\text { the process of actually putting together health status } \\
\text { data reports where we're looking at indicators that } \\
\text { we want to track." (Participant MC3) } \\
\text { "We look at a lot of socio-demographic. We look at } \\
\text { behaviour, risk-behaviour rates, disease rates } \\
\text { locally. That's one source of evidence that we use } \\
\text { quite strongly to measure what we're doing." } \\
\text { (Participant FF4) }\end{array}$ \\
\hline & Expert & Best practice guidelines & Best practice guidelines & $\begin{array}{l}\text { "I know right now the Canadian Centre of } \\
\text { Substance Abuse has just published this whole best } \\
\text { practices guidelines for substance so that's, of } \\
\text { course, what our health promoter is looking at } \\
\text { now." (Participant MA1) }\end{array}$ \\
\hline
\end{tabular}




\begin{tabular}{|c|c|c|c|}
\hline \multirow[t]{2}{*}{ Themes } & \multicolumn{2}{|c|}{ Subthemes } & \multirow[t]{2}{*}{ Example Quotes } \\
\hline & Managers & Frontline Staff & \\
\hline & & & $\begin{array}{l}\text { "In my field, physical activity, we always go back } \\
\text { to our Physical Activity guidelines. And those are } \\
\text { sort of our staple tool, as I'm sure with nutrition." } \\
\text { (Participant FB2) }\end{array}$ \\
\hline \multirow{3}{*}{ Research } & $\begin{array}{l}\text { Peer-reviewed published } \\
\text { literature }\end{array}$ & $\begin{array}{l}\text { Peer-reviewed published } \\
\text { literature }\end{array}$ & $\begin{array}{l}\text { "I suppose literature, published literature, would, } \\
\text { would have a higher degree of credibility." } \\
\text { (Participant MB2) } \\
\text { "The research is ahead of their ability to do that, } \\
\text { and so we are looking to the research to actually tell } \\
\text { us what is new and what is needing to be } \\
\text { addressed." (Participant FB6) }\end{array}$ \\
\hline & Grey literature & Grey literature & $\begin{array}{l}\text { "Well, certainly, certainly literature, but you know, } \\
\text { grey literature as well." (Participant MB2) } \\
\text { "So I would say research and sometimes that's grey } \\
\text { literature too - things that are some of the leading } \\
\text { people in the field what their research, their current } \\
\text { papers and so on what they're publishing or not yet } \\
\text { published but information that they bring to } \\
\text { conference or whatever - that informs our practice." } \\
\text { (Participant FC6) }\end{array}$ \\
\hline & $\begin{array}{l}\text { Guidance documents that are } \\
\text { research-based (OPHS } \\
\text { Standards and other policy } \\
\text { documents) }\end{array}$ & $\begin{array}{l}\text { Guidance documents that } \\
\text { are research-based (OPHS } \\
\text { Standards and other policy } \\
\text { documents) }\end{array}$ & $\begin{array}{l}\text { "There are Regional Standards, there are ... there's } \\
\text { a Regional 10-year Plan that we also have to make } \\
\text { sure that any of our programs can work with it, as } \\
\text { well as Public Health's own 10-year strategic plan. } \\
\text { So we sort of have this list of things... "(Participant } \\
\text { MC5) } \\
\text { "The OPHS is certainly the guiding document, } \\
\text { protocols, and the guidance document supports that. } \\
\text { It is certainly an indication of gaps that are not } \\
\text { addressed." (Participant FD7) }\end{array}$ \\
\hline Experiential & $\begin{array}{l}\text { Lessons from other health } \\
\text { units }\end{array}$ & $\begin{array}{l}\text { Lessons from other health } \\
\text { units }\end{array}$ & $\begin{array}{l}\text { "The other thing I put down was working with other } \\
\text { health units and you know, the linkages that can }\end{array}$ \\
\hline
\end{tabular}




\begin{tabular}{|c|c|c|c|c|}
\hline & \multirow[t]{2}{*}{ Themes } & \multicolumn{2}{|c|}{ Subthemes } & \multirow[t]{2}{*}{ Example Quotes } \\
\hline & & Managers & Frontline Staff & \\
\hline & & & & $\begin{array}{l}\text { happen with that. ... what's been done at other } \\
\text { places that has shown to be effective and evidence } \\
\text { based, and how do you make it your own." } \\
\text { (Participant MD1) } \\
\text { "Well I try to keep in touch with a lot of the Health } \\
\text { Units as well as to what they're currently working } \\
\text { on... See where they get their information; if they } \\
\text { have done an evaluation what are the results of it, to } \\
\text { see if it's something that worthwhile pursuing and } \\
\text { then go from there." (Participant FD3) }\end{array}$ \\
\hline & & $\begin{array}{l}\text { Observing/talking to fellow } \\
\text { practitioners }\end{array}$ & $\begin{array}{l}\text { Observing/talking to fellow } \\
\text { practitioners }\end{array}$ & $\begin{array}{l}\text { "And then I think all of us as practitioners it is } \\
\text { really important because we are on the ground and } \\
\text { we are working with our, with partners, with our } \\
\text { different populations. So, I think that matters a lot." } \\
\text { (Participant MB2) } \\
\text { "And, of course, talking to peers and talking to } \\
\text { people in the community that's also what informs } \\
\text { our service delivery as well." (Participant FF5) }\end{array}$ \\
\hline & & $\begin{array}{l}\text { One's own experiences / } \\
\text { current practice }\end{array}$ & $\begin{array}{l}\text { One's own experiences / } \\
\text { current practice }\end{array}$ & $\begin{array}{l}\text { "I would think our current practice helps to inform } \\
\text { our practice because we are trying to take a really } \\
\text { close look at that." (Participant MD1) } \\
\text { "Probably one thing we're not good at doing ...is } \\
\text { looking at our practice evidence. Like we talk } \\
\text { about it, we learn from our practice." (Participant } \\
\text { FF4) }\end{array}$ \\
\hline \multirow[b]{2}{*}{$\begin{array}{l}\text { Different } \\
\text { Views }\end{array}$} & Local & $\begin{array}{l}\text { NGO websites that are } \\
\text { credible }\end{array}$ & & $\begin{array}{l}\text { "Websites. NGO websites that are credible. That } \\
\text { certainly helps inform practice." (Participant MB2) }\end{array}$ \\
\hline & Expert & $\begin{array}{l}\text { Reports produced by experts } \\
\text { on various topics that impact } \\
\text { or inform practice. }\end{array}$ & & $\begin{array}{l}\text { "I think experts, certainly within the tobacco world, } \\
\text { within the Smoke-Free Ontario strategy groups, like } \\
\text { the Ontario Tobacco Research Unit who produce } \\
\text { reports on various topics that impact - very much } \\
\text { informs practice." (Participant MB2) }\end{array}$ \\
\hline
\end{tabular}




\begin{tabular}{|c|c|c|c|}
\hline Themes & \multicolumn{2}{|c|}{ Subthemes } & \multirow[t]{2}{*}{ Example Quotes } \\
\hline & Managers & Frontline Staff & \\
\hline & & $\begin{array}{l}\text { Best practice evidence from } \\
\text { US }\end{array}$ & $\begin{array}{l}\text { "...we look at different kind of best practices that } \\
\text { have happened, more so in the U.S. and we look at } \\
\text { other places; it's just they seem to be ahead of us } \\
\text { and they have more funding than us I guess." } \\
\text { (Participant FA5) }\end{array}$ \\
\hline \multirow{2}{*}{ Research } & Internal literature reviews & & $\begin{array}{l}\text { "So, each health promoter or dietician in their } \\
\text { program...they're the ones who normally would do } \\
\text { the research to find the evidence. They would be } \\
\text { the ones who are in charge of funding the local need } \\
\text { and looking at the evidence and doing, you know, } \\
\text { reviews." (Participant MA1) }\end{array}$ \\
\hline & $\begin{array}{l}\text { Organizational framework } \\
\text { based on research }\end{array}$ & & $\begin{array}{l}\text { "I think that that framework was ... a lot of work } \\
\text { went into that. We had consultants. There was a lot } \\
\text { of research documents that were looked at to arrive } \\
\text { at that. So I think we all believe that it's grounded } \\
\text { in some pretty solid stuff." (Participant MF6) }\end{array}$ \\
\hline Experiential & & $\begin{array}{l}\text { Past practice (e.g., those of } \\
\text { previous coordinators) }\end{array}$ & $\begin{array}{l}\text { "But I think still ultimately it is past practice and } \\
\text { trying to make it fit, at sort of the end of the day for } \\
\text { what I'm working in anyhow. And as for the other } \\
\text { stuff, still, I think a lot of it is coming from [my } \\
\text { coordinator]. She's the one doing a lot of the work } \\
\text { for evidence-based." (Participant FD2) }\end{array}$ \\
\hline
\end{tabular}

Note: Similarities are highlighted in blue. 


\section{Process for Applying Evidence}

Various processes for applying evidence in program development were described by both managers and frontline staff (Table 5). Differences were found between managers and frontline staff in terms of what processes they use to apply evidence, and also within managers and within frontline staff depending on their particular focus with respect to CDP. Moreover, while OPHS and protocols were not seen as the absolute guiding documents, both managers and frontline staff did recognize that the OPHS provides a foundation for initiating the collection of evidence for program development, that it has created a structure that guides the application of evidence, and that it is something with which all public health work must be aligned. One participant explains the importance of the OPHS:

Probably the one thing that the OPHS has done, is it has made it more - not acceptable, but as a manager, you always - I have been a manager for four years, and you always say, guys, we should evaluate this, we should do this, and then the first thing you get from your staff is ah, I don't want to do it. You know, and I think that, okay, so the reality is, I know we knew we had to do it, but we didn't like doing it. And so we only did it when we had to, or we had or somebody else did it for us. So now, at least with this new process, it has influenced how we plan... (Participant ME3). 
Table 5: Existing processes for applying evidence in CDP program development

\begin{tabular}{|c|c|c|c|}
\hline & \multicolumn{2}{|c|}{ Themes } & \multirow[t]{2}{*}{ Example Quotes } \\
\hline & Managers & Frontline Staff & \\
\hline \multirow[b]{2}{*}{$\begin{array}{c}\text { Similar } \\
\text { Views }\end{array}$} & $\begin{array}{l}\text { Towards Evidence Informed Practice } \\
\text { (TEIP) } \\
\text { General training for interpreting Standards, } \\
\text { and determining how to apply it in practice } \\
\text { to ensure all programs are evidence-based. }\end{array}$ & $\begin{array}{l}\text { Towards Evidence Informed Practice } \\
\text { (TEIP) } \\
\text { General training for interpreting Standards, } \\
\text { and determining how to apply it in practice } \\
\text { to ensure all programs are evidence-based. }\end{array}$ & $\begin{array}{l}\text { "We also provided our teams with a training } \\
\text { called TEIP, which is Towards Evidence- } \\
\text { Informed Practice through OPHA. So all of } \\
\text { the health promotion, disease prevention } \\
\text { branch had participants at this training. So that } \\
\text { they are able to apply the TEIP training now } \\
\text { in our program review to ensure that we are } \\
\text { meeting the Standards." (Participant MB1) } \\
\text { "Well, I think right now, just with our - in } \\
\text { preparation for the Board of Health, we have } \\
\text { been asked to do program assessment using } \\
\text { the TEIP tool." (Participant FB4) }\end{array}$ \\
\hline & $\begin{array}{l}\text { Program Planning and Evaluation } \\
\text { Includes logic models and various tools via } \\
\text { internet to guide the uptake of evidence in } \\
\text { practice. }\end{array}$ & $\begin{array}{l}\text { Program Planning and Evaluation } \\
\text { Includes logic models and various tools via } \\
\text { internet to guide the uptake of evidence in } \\
\text { practice. }\end{array}$ & $\begin{array}{l}\text { "Well we have the program planning and } \\
\text { evaluation process... And it provides us with } \\
\text { some templates in order to move forward on } \\
\text { various programs, so you know including } \\
\text { logic models and various tools that could be } \\
\text { used and they are online or Internet so they're } \\
\text { readily available to us." } \\
\text { (Participant MC3) } \\
\text { "There's a lot of support...to make use of } \\
\text { online supports or whether it's having like } \\
\text { these PPE reps on each team so that when } \\
\text { you're doing your program planning you have } \\
\text { someone that's been trained, I guess, to guide } \\
\text { you with that process." (Participant FC2) }\end{array}$ \\
\hline $\begin{array}{c}\text { Different } \\
\text { Views }\end{array}$ & $\begin{array}{l}\text { Individual-driven } \\
\text { Each individual assesses their own and does } \\
\text { their own programming }\end{array}$ & & $\begin{array}{l}\text { "Right now the process has been each } \\
\text { individual kind of assesses their own and does } \\
\text { their own programming." (Participant MA1) }\end{array}$ \\
\hline
\end{tabular}




\begin{tabular}{|c|c|c|}
\hline \multicolumn{2}{|c|}{ Themes } & \multirow[t]{2}{*}{ Example Quotes } \\
\hline Managers & Frontline Staff & \\
\hline $\begin{array}{l}\text { Ministry-driven } \\
\text { Very prescriptive: just follow the steps or } \\
\text { recommendations suggested }\end{array}$ & & $\begin{array}{l}\text { "...it's very prescriptive, so there is no } \\
\text { decision making done in terms of what are we } \\
\text { going to do. It's like, well, if you've got so } \\
\text { many high risk premises and they better be } \\
\text { done three times a year, they better be done } \\
\text { three times a year." (Participant MA2) }\end{array}$ \\
\hline $\begin{array}{l}\text { Health Information Dissemination } \\
\text { (HIDD) } \\
\text { Established by the MOH, involves a lengthy } \\
\text { tool and a review committee to ensure that } \\
\text { best practice evidence is used in establishing } \\
\text { any program or project }\end{array}$ & & $\begin{array}{l}\text { "... we did have something called the Health } \\
\text { Information Dissemination - HIDD - process, } \\
\text { which our MOH had established to ensure that } \\
\text { we were using best practice evidence in } \\
\text { establishing any program or project. So it was } \\
\text { a very lengthy tool that we would have to } \\
\text { research and demonstrate that we had done } \\
\text { our legwork before establishing a program." } \\
\text { (Participant MB1) }\end{array}$ \\
\hline $\begin{array}{l}\text { Operational planning process } \\
\text { Branch manager carries out a broad scan of } \\
\text { political scene, economy, municipal } \\
\text { demands, the board of health, and the team } \\
\text { to provide a vision of how things will be } \\
\text { done. Team effort. }\end{array}$ & & $\begin{array}{l}\text { "Well from perspective, at the start of every } \\
\text { operational planning period, we normally, and } \\
\text { we will again this year, get training from our } \\
\text { branch manager and sort of setting the tone in } \\
\text { terms of, you know, how - what the process } \\
\text { looks like, what, what we need to be thinking } \\
\text { about, so I feel like that's sort of ..." } \\
\text { (Participant MB2) }\end{array}$ \\
\hline $\begin{array}{l}\text { Formal Process via library services } \\
\text { Teaches how to do properly formulate a } \\
\text { PICO question and then research it } \\
\text { comprehensively }\end{array}$ & & $\begin{array}{l}\text { "There's also a more formal process for ... } \\
\text { that's through our library services in which we } \\
\text { would do a more formal you know PICO } \\
\text { question and research it very thoroughly using } \\
\text { our library services." (Participant MC3) }\end{array}$ \\
\hline $\begin{array}{l}\text { Dedicated planners and health promoters } \\
\text { These individuals take the lead in putting } \\
\text { together evidence, critically appraising it } \\
\text { and then assisting with how to apply this } \\
\text { evidence. }\end{array}$ & & $\begin{array}{l}\text { "And most teams have dedicated planners, or } \\
\text { health promoters who have taken the lead to } \\
\text { kind of help put some of that data together. } \\
\text { With input from all the teams as well, but they } \\
\text { also meet and share among themselves." } \\
\text { (Participant ME2) }\end{array}$ \\
\hline
\end{tabular}




\begin{tabular}{|c|c|c|}
\hline \multicolumn{2}{|c|}{ Themes } & \multirow[t]{2}{*}{ Example Quotes } \\
\hline Managers & Frontline Staff & \\
\hline & $\begin{array}{l}\text { Comprehensive framework } \\
\text { Working with community organizations to } \\
\text { build a relationship, understand their needs, } \\
\text { find the relevant evidence, present to them, } \\
\text { and work together in applying the evidence. }\end{array}$ & $\begin{array}{l}\text { "So the one-offs...to do a display or } \\
\text { presentation that they're [the community is] } \\
\text { used to we're not doing because we want to } \\
\text { do more comprehensive. So instead we work } \\
\text { with that community organization, build a } \\
\text { relationship, and work on you know goals to } \\
\text { achieve together." (Participant FC2) }\end{array}$ \\
\hline & $\begin{array}{l}\text { Practice-Evidence Based (PPE) } \\
\text { Outlines the process of project development, } \\
\text { provides different tools and suggests how to } \\
\text { integrate evidence in practice. }\end{array}$ & $\begin{array}{l}\text { "... we have...Practice-Evidence Based...So, } \\
\text { this has been developed with - you can source } \\
\text { the information based on populations, based } \\
\text { on process within your project development, } \\
\text { or evaluation of needs and blah, blah, blah. } \\
\text { So it's talking about tools, it's talking about } \\
\text { evidence in practice, so the use of different } \\
\text { strategies and so on. So it's addressing many } \\
\text { different components that we are often going } \\
\text { to for helping us supplement with evidence } \\
\text { what we're doing. (Participant FB3) }\end{array}$ \\
\hline & $\begin{array}{l}\text { Evidence-Informed Decision Making } \\
\text { (EIDM) } \\
\text { Process for finding, sharing and using what } \\
\text { works in public health. Includes a set of tools } \\
\text { that guides the process. }\end{array}$ & $\begin{array}{l}\text { "I think there's ... I keep saying all these like } \\
\text { acronyms PPE and EIDM - Program Planning } \\
\text { and Evaluation, Evidence-Informed Decision } \\
\text { Making just for your notes." (Participant FC2) }\end{array}$ \\
\hline & $\begin{array}{l}\text { Program Charters } \\
\text { Allows you to track progress and to ensure } \\
\text { that key benefits or goals sought for the } \\
\text { program are being met. }\end{array}$ & $\begin{array}{l}\text { "Project charters. Like there's a lot of tools so } \\
\text { we put the evidence into these tools to help } \\
\text { our programming. And so we've become } \\
\text { very ... at least we thought of going that } \\
\text { process. But it does slow you down a lot, like } \\
\text { it does, to just go and do what you need to } \\
\text { do." (Participant FC2) }\end{array}$ \\
\hline
\end{tabular}

Note: Similarities are highlighted in blue. 


\section{Facilitators of Evidence Use}

Table 6 describes the types of facilitators within different themes identified by public health managers and frontline staff as supporting their use of evidence in practice. While both managers and frontline staff identified facilitators related to individual, organizational, research

$\underline{\text { itself, }}$ social, and economic factors, only managers discussed how political factors (i.e., having supportive policies) can encourage and promote an increased use of evidence in their practice. 
Table 6: Emergent themes and subthemes regarding facilitators of evidence use

\begin{tabular}{|c|c|c|c|c|}
\hline & Themes & \multicolumn{2}{|c|}{ Subthemes } & \multirow[t]{2}{*}{ Example Quotes } \\
\hline & & Managers & Frontline Staff & \\
\hline \multirow{3}{*}{$\begin{array}{l}\text { Similar } \\
\text { Views }\end{array}$} & \multirow{2}{*}{$\begin{array}{l}\text { Individual } \\
\text { Factors }\end{array}$} & $\begin{array}{l}\text { Being part of networks, } \\
\text { coalitions and working } \\
\text { groups }\end{array}$ & $\begin{array}{l}\text { Being part of networks, } \\
\text { coalitions and working } \\
\text { groups }\end{array}$ & $\begin{array}{l}\text { "Yes, there's lots. I think there's lots of forums } \\
\text { to share the resources, or things that people are } \\
\text { working on. So, for example, at the injury } \\
\text { prevention managers meetings there's an } \\
\text { alliance there now. (Participant MD1) } \\
\text { "I'm on one UV network, I'm on a Listserv, and } \\
\text { then there's tobacco, there's the media networks } \\
\text { as I'm guessing most people, there's a heart } \\
\text { health one and... So they really help you keep } \\
\text { abreast of any new research or any other new } \\
\text { resources and that helps guide us." (Participant } \\
\text { FA5) }\end{array}$ \\
\hline & & $\begin{array}{l}\text { Sharing evidence via email } \\
\text { listservs }\end{array}$ & $\begin{array}{l}\text { Sharing evidence via email } \\
\text { listservs }\end{array}$ & $\begin{array}{l}\text { "There's a lot of papers coming across through } \\
\text { email listservs right now around Ontario } \\
\text { wanting to change our highways and make it } \\
\text { more accessible for bikes." (Participant MA1) } \\
\text { "I think there's a lot of like interprofessional } \\
\text { collaboration...you know networking with other } \\
\text { colleagues or different you know forums or } \\
\text { ListServes to kind of share you know } \\
\text { information or kind of best practices and stuff } \\
\text { like that and you know current literature." } \\
\text { (Participant FC7) }\end{array}$ \\
\hline & $\begin{array}{l}\text { Organizational } \\
\text { Factors }\end{array}$ & $\begin{array}{l}\text { In-house epidemiologist or a } \\
\text { designated person who } \\
\text { compiles all evidence }\end{array}$ & $\begin{array}{l}\text { In-house epidemiologist or a } \\
\text { designated person who } \\
\text { compiles all evidence }\end{array}$ & $\begin{array}{l}\text { "We look at our epidemiology pieces with our } \\
\text { you know health-specific data with our Epi } \\
\text { Department and most, I think, most programs } \\
\text { are going through the process of actually putting } \\
\text { together health status data reports where we're } \\
\text { looking at indicators that we want to track." } \\
\text { (Participant MC3) }\end{array}$ \\
\hline
\end{tabular}




\begin{tabular}{|c|c|c|c|c|}
\hline & \multirow[t]{2}{*}{ Themes } & \multicolumn{2}{|c|}{ Subthemes } & \multirow[t]{2}{*}{ Example Quotes } \\
\hline & & Managers & Frontline Staff & \\
\hline & & & & $\begin{array}{l}\text { "We also have an epidemiologist that does } \\
\text { ongoing reports so we have a Chronic Disease } \\
\text { Prevention report. So the information that comes } \\
\text { out of that we use to move forward might create } \\
\text { a priority in our health unit, for example, or have } \\
\text { evidence to support whatever we are doing in } \\
\text { the community." (Participant FA6) }\end{array}$ \\
\hline & Research Itself & $\begin{array}{l}\text { Websites providing evidence } \\
\text { syntheses }\end{array}$ & $\begin{array}{l}\text { Websites providing evidence } \\
\text { syntheses }\end{array}$ & $\begin{array}{l}\text { "Websites. NGO websites that are credible." } \\
\text { (Participant MB2) } \\
\text { "Dieticians of Canada has practiced evidence- } \\
\text { based nutrition, a PEN database it's called, P-E- } \\
\text { N, so I refer to that often like for nutrition } \\
\text { content..." (Participant FF5) }\end{array}$ \\
\hline & Social Factors & $\begin{array}{l}\text { Linkages with other health } \\
\text { units }\end{array}$ & $\begin{array}{l}\text { Linkages with other health } \\
\text { units }\end{array}$ & $\begin{array}{l}\text { "The other thing I put down was working with } \\
\text { other health units and you know, the linkages } \\
\text { that can happen with that." (Participant MD1) } \\
\text { "When we look generally at something broader } \\
\text { there's a very good network in Ontario for } \\
\text { nutritionists that is called OSNPPH the Ontario } \\
\text { Society of Nutrition Personnel and Public } \\
\text { Health, and we often share the projects or } \\
\text { success stories, things that we get transferred } \\
\text { from one health unit to another." (Participant } \\
\text { FD7) }\end{array}$ \\
\hline & $\begin{array}{l}\text { Economic } \\
\text { Factors }\end{array}$ & $\begin{array}{l}\text { Money invested in resource } \\
\text { centres }\end{array}$ & $\begin{array}{l}\text { Money invested in resource } \\
\text { centres }\end{array}$ & $\begin{array}{l}\text { "...but I also use a lot of resources from Health } \\
\text { Canada, also the Nutrition Resource Centre, a } \\
\text { provincial organization." (Participant FF5) }\end{array}$ \\
\hline $\begin{array}{l}\text { Different } \\
\text { Views }\end{array}$ & $\begin{array}{l}\text { Individual } \\
\text { Factors }\end{array}$ & & $\begin{array}{l}\text { One-on-one expertise / } \\
\text { mentoring capacity }\end{array}$ & $\begin{array}{l}\text { "I think we have been fortunate in our nutrition } \\
\text { group specifically because we have had a } \\
\text { supervisor that's very keen on assessment and } \\
\text { evaluation... And I think that's served us very } \\
\text { well..." (Participant FB6) }\end{array}$ \\
\hline
\end{tabular}




\begin{tabular}{|c|c|c|c|}
\hline \multirow[t]{2}{*}{ Themes } & \multicolumn{2}{|c|}{ Subthemes } & \multirow[t]{2}{*}{ Example Quotes } \\
\hline & Managers & Frontline Staff & \\
\hline \multirow{6}{*}{$\begin{array}{l}\text { Organizational } \\
\text { Factors }\end{array}$} & $\begin{array}{l}\text { Access to external library } \\
\text { service }\end{array}$ & & $\begin{array}{l}\text { "So I actually relied on that library to help me } \\
\text { with big literature review to guide the } \\
\text { evidence." (Participant MA1) }\end{array}$ \\
\hline & & $\begin{array}{l}\text { Fact sheets as part of } \\
\text { operational plans }\end{array}$ & $\begin{array}{l}\text { "Well, in the past, and I'm not even sure if it } \\
\text { still happens, but for our operational plans on } \\
\text { the face sheet we have to explain why we were } \\
\text { doing this, like what evidence, what we were } \\
\text { basing these activities or programs on." } \\
\text { (Participant FA5) }\end{array}$ \\
\hline & & $\begin{array}{l}\text { Practice groups within the } \\
\text { health unit }\end{array}$ & $\begin{array}{l}\text { "And then the other one is Nutrition Practice } \\
\text { Groups, so at that one you talk about best } \\
\text { practices and also bring, for example, a research } \\
\text { study or something or some kind of recent } \\
\text { announcement on guidelines or something like } \\
\text { that and talk about it together." (Participant } \\
\text { FC1) }\end{array}$ \\
\hline & & $\begin{array}{l}\text { Expanded in-house library } \\
\text { services }\end{array}$ & $\begin{array}{l}\text { "But certainly the library I think has kind of } \\
\text { exploded in what they can offer and what they } \\
\text { have access to and what we pay for to have } \\
\text { access to." (Participant FC6) }\end{array}$ \\
\hline & & $\begin{array}{l}\text { Online courses, modules, and } \\
\text { webinars supported through } \\
\text { management }\end{array}$ & $\begin{array}{l}\text { "They're very frequently used. I think we all } \\
\text { participate in the fireside chats, and the [online] } \\
\text { webinars, and that's been something that's been } \\
\text { really helpful." (Participant FB2) }\end{array}$ \\
\hline & & $\begin{array}{l}\text { Training sessions and } \\
\text { workshops }\end{array}$ & $\begin{array}{l}\text { "I had wanted to get there too, but the } \\
\text { qualitative and the quantitative, and I think } \\
\text { slowly you are being trained more on both so } \\
\text { some of us have started to go to the McMaster } \\
\text { training... So I think our perception as it is now } \\
\text { in } 5 \text { years from now will be very different as it } \\
\text { filters." (Participant FC2) }\end{array}$ \\
\hline Research Itself & $\begin{array}{l}\text { Availability of provincial } \\
\text { evidence }\end{array}$ & & $\begin{array}{l}\text { "And so definitely that, the direction is very } \\
\text { much supporting, you know, regionally-focused } \\
\text { planning, regionally-focused implemented } \\
\text { campaigns, and province, sort of mixing into }\end{array}$ \\
\hline
\end{tabular}




\begin{tabular}{|c|c|c|c|}
\hline \multirow[t]{2}{*}{ Themes } & \multicolumn{2}{|c|}{ Subthemes } & \multirow[t]{2}{*}{ Example Quotes } \\
\hline & Managers & Frontline Staff & \\
\hline & & & $\begin{array}{l}\text { that to make it - to get you the best bang for } \\
\text { your buck, essentially." (Participant MB2) }\end{array}$ \\
\hline & & $\begin{array}{l}\text { In-house research } \\
\text { units/divisions }\end{array}$ & $\begin{array}{l}\text { "We used to have research units...And I would } \\
\text { call (indiscernible) and would say, okay we are } \\
\text { teaching about eating disorders in school } \\
\text { classrooms, is it effective." (Participant FD7) }\end{array}$ \\
\hline & & $\begin{array}{l}\text { Access to clearing house best } \\
\text { practices databases }\end{array}$ & $\begin{array}{l}\text { "One thing too, there is an enormous amount of } \\
\text { clearing house best practice guideline sources." } \\
\text { (Participant FB2) }\end{array}$ \\
\hline & & $\begin{array}{l}\text { Availability of past practice } \\
\text { evidence (through } \\
\text { coordinators) }\end{array}$ & $\begin{array}{l}\text { "But I think still ultimately it is past practice and } \\
\text { trying to make it fit, at sort of the end of the day } \\
\text { for what I'm working in anyhow. And as for the } \\
\text { other stuff, still, I think a lot of it is coming from } \\
\text { [my coordinator]. She's the one doing a lot of } \\
\text { the work for evidence-based." (Participant FD2) }\end{array}$ \\
\hline \multirow{3}{*}{ Social Factors } & & Conferences & $\begin{array}{l}\text { "The other thing too, is often a lot of the } \\
\text { interesting new innovations and things are - } \\
\text { they're given at conferences." (Participant FB2) }\end{array}$ \\
\hline & & $\begin{array}{l}\text { Linkages with medical } \\
\text { schools or other institutions } \\
\text { that can do research for you }\end{array}$ & $\begin{array}{l}\text { "If you posed to them a research question } \\
\text { "poof" they'll come out with a review and say, } \\
\text { okay, "we think those six articles will help you } \\
\text { with your information" and they do the research } \\
\text { for you. So they provide us training maybe once } \\
\text { a year and if you don't do it enough then they'll } \\
\text { do the first or the second one for you to help } \\
\text { you." (Participant FD7) }\end{array}$ \\
\hline & & $\begin{array}{l}\text { Partnerships within the } \\
\text { community }\end{array}$ & $\begin{array}{l}\text { "...with all the partnerships within the } \\
\text { community, it gives us the opportunity to reach } \\
\text { out to the community partners and kind of } \\
\text { collaborate to work together to make some use } \\
\text { of that evidence." (Participant FA7) }\end{array}$ \\
\hline $\begin{array}{l}\text { Political } \\
\text { Factors }\end{array}$ & Supportive policies & & $\begin{array}{l}\text { "And Smoke Free Ontario Act was like the } \\
\text { greatest thing to happen because that's where } \\
\text { you really saw some of the change. So I think } \\
\text { it's a big help to have it. And same with the }\end{array}$ \\
\hline
\end{tabular}




\begin{tabular}{|l|l|l|l|l|}
\hline & Themes & \multicolumn{2}{|c|}{ Subthemes } & Example Quotes \\
\hline & & Managers & Frontline Staff & \\
\hline & & & $\begin{array}{l}\text { school food policies. The fact that that was } \\
\text { provincial, I think that would have been a really } \\
\text { tough sell for individual schools to just kind of } \\
\text { accept that on their own.” (Participant MA1) }\end{array}$ \\
\hline
\end{tabular}

Note: Similarities are highlighted in blue. 


\section{Barriers to Implementing Evidence}

Table 7 describes the types of barriers within different themes as experienced by public health managers and frontline staff when implementing evidence in their practice. While both managers and frontline staff experienced barriers related to individual, organizational, research $\underline{\text { itself, }}$ economic and political factors, only frontline staff discussed how social factors influence their implementation efforts. 
Table 7: Emergent themes and subthemes regarding barriers to implementing evidence

\begin{tabular}{|c|c|c|c|c|}
\hline & \multirow[t]{2}{*}{ Themes } & \multicolumn{2}{|c|}{ Subthemes } & \multirow[t]{2}{*}{ Example Quotes } \\
\hline & & Managers & Frontline Staff & \\
\hline \multirow{4}{*}{$\begin{array}{l}\text { Similar } \\
\text { Views }\end{array}$} & \multirow{4}{*}{$\begin{array}{c}\text { Individual } \\
\text { Factors }\end{array}$} & Language-related barriers & Language-related barriers & $\begin{array}{l}\text { "Another barrier there that has been identified is } \\
\text { that we don't, we don't have the francophone } \\
\text { capacity to...extrapolate francophone data" } \\
\text { (Participant MB1) } \\
\text { "at first if you want to be a breast feeding buddy } \\
\text { you have to be bilingual because all the training } \\
\text { will be provided in English and yet you will be } \\
\text { providing the service in French because we don't } \\
\text { have internal capacity to train in French." } \\
\text { (Participant FD7) }\end{array}$ \\
\hline & & Time constraints & Time constraints & $\begin{array}{l}\text { "I think, again, it is a bit of the time limitation } \\
\text { thing. You value the evidence that you have time } \\
\text { and ability to collect often, more than others." } \\
\text { (Participant ME1) } \\
\text { "I know where to go for information, I know for } \\
\text { nutrition how to get it. But it's the time to do it } \\
\text { and the time to do that search and to compile that } \\
\text { information and put it together. With everything I } \\
\text { have to do its very time consuming and that's one } \\
\text { big barrier for me." (Participant FD1) }\end{array}$ \\
\hline & & Lack of leadership & Lack of leadership & $\begin{array}{l}\text { "Well I would say the willingness of our senior } \\
\text { management to be out in front of an issue as } \\
\text { opposed to coming in behind where it's ..." } \\
\text { (Participant MF5) } \\
\text { "So I don't know if it's a lack of leadership or a } \\
\text { lack of confidence on their part to just say, no } \\
\text { we're going to do what we're obligated to do } \\
\text { which are these evidence-based practices and } \\
\text { saying no to the old stuff." (Participant FD4) }\end{array}$ \\
\hline & & Attitudes towards change & Attitudes towards change & "Well, some more like staff sort of issues would \\
\hline
\end{tabular}




\begin{tabular}{|c|c|c|c|}
\hline \multirow[t]{2}{*}{ Themes } & \multicolumn{2}{|c|}{ Subthemes } & \multirow[t]{2}{*}{ Example Quotes } \\
\hline & Managers & Frontline Staff & \\
\hline & & & $\begin{array}{l}\text { be possibly implementing new things. Like } \\
\text { everyone is sort of afraid of change to some } \\
\text { degree." (Participant MA1) } \\
\text { "I think certain team members are more ... } \\
\text { embrace the change and the direction and others } \\
\text { are resistant and those people who are resistant } \\
\text { provide a barrier to the team moving forward." } \\
\text { (Participant FC6) }\end{array}$ \\
\hline & $\begin{array}{l}\text { Competence in identifying } \\
\text { evidence and doing } \\
\text { evidence-based programs }\end{array}$ & $\begin{array}{l}\text { Competence in identifying } \\
\text { evidence and doing evidence- } \\
\text { based programs }\end{array}$ & $\begin{array}{l}\text { "You know, where should we go next, kind of } \\
\text { stuff, has been very valuable. So in terms of } \\
\text { barrier, I don't think that we have enough staff to } \\
\text { be able to [interpret and analyze evidence]." } \\
\text { (Participant MB1) } \\
\text { "So that's definitely a challenge for people that } \\
\text { have never ... don't know where to look, don't } \\
\text { know what to do with it, and then present it and } \\
\text { say this is what we're going to use." (Participant } \\
\text { FC3) }\end{array}$ \\
\hline \multirow{2}{*}{$\begin{array}{c}\text { Economic } \\
\text { Factors }\end{array}$} & Availability of staffing & Availability of staffing & $\begin{array}{l}\text { "So I think that that, for us, that that was our } \\
\text { biggest barrier is, is money. And capacity." } \\
\text { (Participant MB1) } \\
\text { "So that's definitely - just because there's } \\
\text { evidence there doesn't mean that you necessarily } \\
\text { have the capacity to follow through with all that } \\
\text { evidence." (Participant FA7) }\end{array}$ \\
\hline & Availability of funding & Availability of funding & $\begin{array}{l}\text { "Where we had the Youth Action alliances, we } \\
\text { had the evidence that has had impact, the } \\
\text { message from the Ministry is, "that's too } \\
\text { expensive, we can't continue funding it." But we } \\
\text { know that it changes behaviours." (Participant } \\
\text { MB1) }\end{array}$ \\
\hline
\end{tabular}




\begin{tabular}{|c|c|c|c|c|}
\hline & \multirow[t]{2}{*}{ Themes } & \multicolumn{2}{|c|}{ Subthemes } & \multirow[t]{2}{*}{ Example Quotes } \\
\hline & & Managers & Frontline Staff & \\
\hline & & & & $\begin{array}{l}\text { "...because you may have all the evidence in the } \\
\text { world to say you should do something but if you } \\
\text { don't have the money to be able to move on that } \\
\text { properly then that can be a barrier." (Participant } \\
\text { FC1) }\end{array}$ \\
\hline & & $\begin{array}{l}\text { Short accountability } \\
\text { timeframe }\end{array}$ & $\begin{array}{l}\text { Short accountability } \\
\text { timeframe }\end{array}$ & $\begin{array}{l}\text { "Well in this complex environment it takes you a } \\
\text { year and a half, } 2 \text { years, to develop that } \\
\text { partnership, let alone start seeing any kinds of ... } \\
\text { So it is really challenging. And you run the risk } \\
\text { of showing no impact and lack of effectiveness } \\
\text { because the timeframes are so short." (Participant } \\
\text { MF1) } \\
\text { "And with for-profit companies they measure } \\
\text { their success by the quarter and, you know, in a } \\
\text { quarter year if you don't have profit coming in, } \\
\text { then we need to get rid of something - and so } \\
\text { workplace health seems to take a back seat in a } \\
\text { lot of for-profit companies." (Participant FA1) }\end{array}$ \\
\hline & $\begin{array}{l}\text { Political } \\
\text { Factors }\end{array}$ & $\begin{array}{l}\text { Conflict with municipal } \\
\text { mandates and reliance on } \\
\text { city councillors' support }\end{array}$ & $\begin{array}{l}\text { Conflict with municipal } \\
\text { mandates and reliance on city } \\
\text { councillors' support }\end{array}$ & $\begin{array}{l}\text { "The focus of our accountability I think will be } \\
\text { more so given our you know municipal mandates } \\
\text { and you know councillors will be looking at the } \\
\text { immediate to short term kind of focus, and with } \\
\text { an emphasis on those customer services that } \\
\text { we're talking about." (Participant MF1) } \\
\text { "...people in the subdivisions would make } \\
\text { deputations to council and have petitions and get } \\
\text { everybody on board to say no sidewalk, no } \\
\text { sidewalk and council is like, okay no sidewalk." } \\
\text { (Participant FA2) }\end{array}$ \\
\hline $\begin{array}{l}\text { Different } \\
\text { Views }\end{array}$ & $\begin{array}{c}\text { Organizational } \\
\text { Factors }\end{array}$ & Governance structure & & $\begin{array}{l}\text { "And maybe some of that has to do with our } \\
\text { particular structure...And other Boards of Health } \\
\text { may have a little bit more freedom to be risk } \\
\text { takers because they're not quite so tied to the }\end{array}$ \\
\hline
\end{tabular}




\begin{tabular}{|c|c|c|c|}
\hline \multirow[t]{2}{*}{ Themes } & \multicolumn{2}{|c|}{ Subthemes } & \multirow[t]{2}{*}{ Example Quotes } \\
\hline & Managers & Frontline Staff & \\
\hline & & & $\begin{array}{l}\text { municipal governance structure.” (Participant } \\
\text { MF5) }\end{array}$ \\
\hline & Need to prioritize & & $\begin{array}{l}\text { "And I think the other barrier to implementing } \\
\text { evidence, and you have probably alluded to this a } \\
\text { bit, is the need to prioritize...you know, what we } \\
\text { put into our plans, okay these are the services we } \\
\text { will continue, these are the services that we're } \\
\text { stopping." (Participant MD1) }\end{array}$ \\
\hline & $\begin{array}{l}\text { Proportion of staff dedicated } \\
\text { towards evidence-collecting } \\
\text { versus delivery of service: } \\
\text { balance }\end{array}$ & & $\begin{array}{l}\text { "Well, it's always...the struggle between } \\
\text { servicing the population and you know, what } \\
\text { proportion of your staff is dedicated to that } \\
\text { evidence-collecting piece versus the delivery of } \\
\text { service that's required. So what is that balance." } \\
\text { (Participant MB2) }\end{array}$ \\
\hline & & Structure of the health unit & $\begin{array}{l}\text { "So now I have to train; sometimes it's a pop } \\
\text { health nurse, sometimes its family health nurses, } \\
\text { because it is zero to six, well really - healthy } \\
\text { eating happens zero to six and beyond. So there } \\
\text { are silos to be broken there." (Participant FD7) }\end{array}$ \\
\hline & & $\begin{array}{l}\text { Failures not shared as } \\
\text { successes are }\end{array}$ & $\begin{array}{l}\text { "if something is a failure it just gets put aside; it's } \\
\text { the unmentionable, rather than that is evidence. } \\
\text { That is available and we should be learning." } \\
\text { (Participant FB2) }\end{array}$ \\
\hline & & $\begin{array}{l}\text { Lack of proper training on } \\
\text { identifying a priority } \\
\text { population }\end{array}$ & $\begin{array}{l}\text { "I think a big barrier for me, is what is a priority } \\
\text { population....and our health unit, as far as I am } \\
\text { concerned, hasn't offered any sort of, how are we } \\
\text { going to do that. You are kind of left to figure it } \\
\text { out." (Participant FE2) }\end{array}$ \\
\hline & & $\begin{array}{l}\text { Organizational direction } \\
\text { towards behaviour-change } \\
\text { instead of awareness-raising }\end{array}$ & $\begin{array}{l}\text { "We've gathered the information; it seems to } \\
\text { have been effective. But it was effective [in] } \\
\text { awareness-raising in the target population. It } \\
\text { wasn't effective in creating behaviour change. } \\
\text { And so it wasn't comprehensive...so its been } \\
\text { pulled." (Participant FC6) }\end{array}$ \\
\hline
\end{tabular}




\begin{tabular}{|c|c|c|c|}
\hline \multirow[t]{2}{*}{ Themes } & \multicolumn{2}{|c|}{ Subthemes } & \multirow[t]{2}{*}{ Example Quotes } \\
\hline & Managers & Frontline Staff & \\
\hline \multirow{4}{*}{ Research Itself } & $\begin{array}{l}\text { Need for more provincial } \\
\text { evidence }\end{array}$ & & $\begin{array}{l}\text { "We're just wondering why, each individual } \\
\text { health unit, why are we all struggling and } \\
\text { spinning our wheels trying to do the same thing; } \\
\text { that's a lot of time and resource, when the } \\
\text { province could just say, okay you know what, } \\
\text { let's just do something provincially... and get it } \\
\text { taken care." (Participant MA1) }\end{array}$ \\
\hline & Accessibility and availability & & $\begin{array}{l}\text { "I think accessibility and availability. I think } \\
\text { evidence needs to be in, you know, nice neat } \\
\text { packages. Like even the guidance documents are } \\
\text { so big that you really have to comb through them } \\
\text { and look to see if there's certain ideas." } \\
\text { (Participant MD1) }\end{array}$ \\
\hline & & $\begin{array}{l}\text { Finding and maintaining } \\
\text { current statistics and evidence }\end{array}$ & $\begin{array}{l}\text { "In any event, with the smoke-free movies } \\
\text { campaign where there are well researched, peer- } \\
\text { reviewed journal articles that are published on it, } \\
\text { something like that, the movies that they're } \\
\text { referencing are already a few years old so they } \\
\text { don't really resonate with the youth as much } \\
\text { when you're using that research." (Participant } \\
\text { FA5) }\end{array}$ \\
\hline & & $\begin{array}{l}\text { Information overload: too } \\
\text { much evidence to grasp }\end{array}$ & $\begin{array}{l}\text { "One thing too, there is an enormous amount of } \\
\text { clearing house best practice guideline sources. } \\
\text { It's almost overwhelming, to the point where you } \\
\text { go to this website and there's } 2000 \text { best practices } \\
\text { for a project and it's almost information } \\
\text { overload." (Participant FB2) }\end{array}$ \\
\hline Social Factors & & $\begin{array}{l}\text { People do not recognize the } \\
\text { benefits of chronic disease } \\
\text { prevention }\end{array}$ & $\begin{array}{l}\text { "I think one of the biggest barriers is that people } \\
\text { in general in Public Health and outside they don't } \\
\text { recognize the benefit of Chronic Disease } \\
\text { Prevention...because it's not acute care. It's not } \\
\text { a person's going to get better. You're going to } \\
\text { save their life. They just don't see the long-term } \\
\text { benefit at all." (Participant FF5) }\end{array}$ \\
\hline
\end{tabular}




\begin{tabular}{|c|c|c|c|}
\hline \multirow[t]{2}{*}{ Themes } & \multicolumn{2}{|c|}{ Subthemes } & \multirow[t]{2}{*}{ Example Quotes } \\
\hline & Managers & Frontline Staff & \\
\hline & & $\begin{array}{l}\text { Barrier for a partnership in } \\
\text { the area due to: } \\
\text { - Cultural constraints } \\
\text { - Loss of credibility as } \\
\text { service providers } \\
\text { Power dynamics: public } \\
\text { health seen as funders, not as } \\
\text { partners }\end{array}$ & $\begin{array}{l}\text { "...we were going to do an event [around tobacco } \\
\text { prevention outside of the school and we needed } \\
\text { permission from the principals, but there was } \\
\text { backlash from the parents and the community that } \\
\text { were in the tobacco farming business or } \\
\text { industry..." (Participant FA5) }\end{array}$ \\
\hline $\begin{array}{l}\text { Economic } \\
\text { Factors }\end{array}$ & & $\begin{array}{l}\text { Duplication of services with } \\
\text { other sectors and within the } \\
\text { health sector with CHCs. }\end{array}$ & $\begin{array}{l}\text { "But we have just realized lately that even within } \\
\text { our city, there are other groups sometimes that } \\
\text { are doing things similar. Like, I'm thinking } \\
\text { Parks and Rec with you guys, that's a direct } \\
\text {...duplication, slash, slash." (Participant FB3) }\end{array}$ \\
\hline $\begin{array}{l}\text { Political } \\
\text { Factors }\end{array}$ & & $\begin{array}{l}\text { Evidence not consistently } \\
\text { valued at all levels in the } \\
\text { municipality. }\end{array}$ & $\begin{array}{l}\text { "[Evidence is] valued in health but not elsewhere, } \\
\text { so if you're working in an environment where } \\
\text { you're working closely and you are trying to be } \\
\text { collaborative and integrate, it's difficult when } \\
\text { you have very difficult core values." (Participant } \\
\text { FB2) }\end{array}$ \\
\hline
\end{tabular}

Note: Similarities are highlighted in blue. 
In summary, public health frontline staff and their managers agreed that there are diverse types of evidence. Both similarities and differences were found in terms of what evidence types managers and frontline staff use as well as the processes they utilize for applying the evidence to inform or guide their practice with respect to the CDP activities. Moreover, there were also areas of consistency and inconsistency between managers and frontline staff with respect to facilitators identified as promoting evidence use as well as barriers to implementing evidence.

\section{Discussion}

Ontario public health policy requires public health programs to be based on evidence. To examine how this policy is enacted in the field, this qualitative descriptive study examined understandings about evidence in Ontario public health units by comparing perspectives from managers and frontline staff across six geographically-diverse units. The analysis revealed similarities and differences with respect to: 1) meanings of evidence; 2) types of evidence guiding practice; 3) process for applying evidence; 4) facilitators of evidence use; and 5) barriers to implementing evidence. The overall finding that there are differences in how public health frontline staff and their managers view, practice and apply evidence support the claim that individuals from different educational backgrounds and/or disciplines, belonging to different value systems, and performing a different set of professional roles tend to perceive evidence differently (Langley and Denis, 2011).

In terms of the meanings of evidence, the findings of this study suggest that both public health managers and frontline staff have a similar understanding of evidence: that multiple forms of evidence exist. This understanding of evidence is consistent with what literature has reported about what constitutes evidence and the different types of evidence that exist (e.g., Bhattacharyya et al., 2009), including in the public health context (Kamper-Jõrgensen, 2000; 
Kothari et al., 2015). Another aspect of evidence meaning that emerged from participant responses was that different participants used a range of different words to describe an evidence type, for example words such as "impact", "proof", "evaluated", "what works" and "justification", suggesting that policies guiding practice might do well to include a clear, broad definition of "evidence".

In terms of the types of evidence guiding practice, both frontline staff and their managers mentioned that they use various sources of evidence and evidence types to inform or guide their practice. Moreover, participants described that their choice of evidence is context-dependent as well as program-dependent. This aligns with a number of studies that have shown that an integration of knowledge is often carried out within the public health context and that this integration can vary depending on the stage of program planning (Higgins et al., 2011; Kothari et al., 2012; Meagher-Stewart et al., 2012; Yousefi-Nooraei et al., 2014). In terms of the differences between managers and frontline staff, the types of evidence used by frontline staff were based on practice evidence (e.g., practice evidence from other jurisdictions, past practice), whereas managers focused more on research-based documents.

Fortunately, both managers and frontline staff noted that there are different ways that (practice, research) evidence comes together and there are some processes already in place to support evidence integration and use. However, more differences than similarities were found in terms of the types of processes used. One of the key differences was that only frontline staff talked about using a comprehensive framework process to applying evidence in practice, which involved building ongoing connections with community organizations. Managers, on the other hand, pointed to external resources such as library services that could assist with the use of evidence. The difference in processes may be because these two groups have different 
professional roles and responsibilities in public health (Langley and Denis, 2011). For example, frontline staff spend more time in the actual field delivering the program and services to the target populations in collaboration with other groups carrying out public health work.

In terms of factors influencing evidence use, a set of different barriers and facilitators of evidence use was discussed by managers and frontline staff. Nevertheless, in terms of common views, the findings suggest that strategies such as networks, listservs, websites and connecting with other health units are acceptable ways to promote the use of evidence. But frontline staff identified more facilitators than managers, suggesting that there are more opportunities to promote the use of evidence to this group. Frontline staff also suggested that capacity building through training and communities of practice are viable ways to support evidence use. In terms of barriers, both groups identified competencies, attitudes and leadership as challenges if they are not supportive of the evidence-based solution for public health problems. On the other hand, strong leadership can help bring about change at all levels (especially at the organizational level). The understanding of leadership differed between frontline staff and managers in Ontario public health units. For frontline staff, leadership meant managers, and for managers, leadership meant senior administration or management (e.g., directors). Perhaps relatedly, staff also identified a number of organizational barriers that could be amenable to change. This understanding of differences in barriers and facilitators could allow individuals involved in knowledge translation (KT) to strategically select, tailor and implement KT strategies that meet the specific needs of both public health managers and frontline staff.

In the following sections, key implications for policy and practice are discussed: 


\section{Implications for Policy}

Public health policies are developed at multiple levels: federal, provincial, regional and local. Given the findings of this research, policy makers responsible for developing public health policies at the provincial level can contribute to promoting further use of evidence in public health practice in three possible ways. First, although managers and frontline staff understood the concept of evidence in the same way, it would be useful for provincial policy makers to be clear about what they mean by evidence. This will ensure that there are no gaps between what is communicated by policy makers through broad strategic direction or guidelines presented in provincial policy and what actually gets operationalized by managers and frontline staff in their daily work at the regional and local level. Second, frontline staff and their managers agreed that diverse types of evidence are useful to inform their practice. An implication of this finding is that policy makers need to acknowledge and incorporate various forms of evidence in making provincial policy decisions. Third, both managers and frontline staff identified various supports at the organizational level (e.g., access to library services, in-house epidemiologist) for promoting evidence use in practice. Such services are often not possible without proper funding and supportive policies. Therefore, policy makers responsible for developing provincial policy can play an important role in sustaining the existing supports in public health units as well as in providing additional supports

\section{Implications for Practice}

Three major practice implications can be drawn from this research. The major finding of this research is that frontline staff and their managers have different perspectives related to some aspects of evidence and evidence use. Some managers and frontline staff shared that they come together to engage in mutual discussions about evidence in a context- or program-specific way. 
These groups found such discussions to be very effective in allowing them to identify a similar goal around evidence and to look at the varieties of evidence that inform public health services. However, other managers and frontline staff identified lack of such mutual discussions in their groups as a problem. In order to better understand each others' views about evidence and needs to support evidence use, it would be useful for all managers and frontline staff to engage in mutual discussions about their understanding of evidence and how their use of evidence in practice is influenced by various factors. Organizing and using deliberative dialogues is one way to involve managers and frontline staff as key action agents in policy making and to gain better knowledge of both their perspectives and the contexts in which their actions are operationalized (Lavis et al., 2009).

Another finding that emerged from this research was that there are different ways that evidence comes together, that there are different sources of evidence, and there are some processes already in place to support evidence use. Practitioners should incorporate and apply those tools in practice that are not exclusively focused on research evidence but instead focused on integrating various sources of evidence. Moreover, while both managers and frontline staff identified websites providing evidence syntheses as one of the facilitators, they identified the lack of competency in identifying relevant evidence and doing evidence-based programs as one of the barriers. One way these two groups can resolve this issue is by getting involved in more online courses, modules, and webinars available internally (identified as another facilitator by frontline staff) as well as looking out for courses that build research skills at other institutions (e.g., universities). Given that both managers and frontline staff experience time constraints, it is very important to create an organizational culture where competency in identifying relevant evidence is valued, where organizational resources are available to support involvement in 
courses, and where leadership (which consists of managers for frontline staff and senior administration for managers) is supportive of the evidence-based solution.

\section{Limitations}

The findings need to be considered in light of study limitations. In terms of carrying out a secondary analysis of qualitative data, there was a dependence on using focus group questions designed by the RePHS team for their purpose to answer the research question investigated in this study. Although both the primary RePHS study and this study were about the same phenomenon, RePHS study had a slightly different research focus and involved various topics in addition to evidence in their discussions. Therefore, the data used may not necessarily be of best depth and pertinent detail for this particular secondary analysis (Hinds et al., 1997). However, this limitation was addressed by focusing analysis on responses from evidence-specific questions. This ensured that data which specifically represented views of participants about evidence were analyzed.

Another limitation is the reliance on original researchers for the quality of data collected. This is a challenge for all secondary analysis studies, including this one, as researchers have no opportunity to interact with participants or to make observations, and had no control over managing the quality of data gathered. This lack of first-hand experience limits the level of tacit knowledge a researcher has about participants whose perspectives are expressed and about the setting and culture informing these perspectives (Hammersley, 1997). Therefore, understandings of the context and thus interpretations were made on the basis of information found within the transcripts. To address this limitation, iterative discussions were held with AK and SR, both of whom are part of the primary RePHS research team and provided guidance throughout the conduct of this research study. 


\section{Conclusion}

In conclusion, this study provides a detailed description of how public health managers and frontline staff view and use evidence in their practice. The findings of this study could be helpful in developing strategies to improve the implementation of the OPHS and to promote an increased use of evidence-informed interventions and large-scale projects that are effective across public health units in Ontario. Future research could undertake an analysis that provides insight on different ways in which evidence is actioned in practice.

\section{Declarations}

\section{Acknowledgements}

This research was funded by a CIHR Emerging Team Grant (FRN \#92255) "Renewal of Public Health Systems (RePHS) in BC and Ontario" to Drs. M. MacDonald, T. Hancock and B. Pauly, Principal Investigators). The authors would like to thank the research team of primary RePHS project for approving the study proposal, for providing access to RePHS Phase I data, and for their review of this manuscript.

\section{Authors' contributions}

All authors jointly conceptualized the work and were involved during all stages of this research. SM led the development of the manuscript. AK and SR contributed to the critical revision of the manuscript. All authors read and approved the final manuscript.

\section{Competing interests}

The authors declare they have no competing interests.

\section{Notes}

${ }^{1}$ Local evidence was defined as knowledge of local sources shaped by an individual's local context and related factors; Expert evidence was defined as knowledge obtained from formal education and/or training in a given area of practice; Research evidence was defined as knowledge that comes from empirical observations made using scientific methods; Experiential evidence was defined as knowledge gained from learning experiences in a particular field of practice (Kothari et al., 2015). 


\section{References}

Armstrong, R, Waters, E, Moore, L, Dobbins, M, Pettman, T, Burns, C, Swinburn, B, Anderson, L, Petticrew, M, 2014, Understanding evidence: a statewide survey to explore evidenceinformed public health decision-making in a local government setting, Implementation Science 9, 188

Bhattacharyya, O, Reeves, S, Zwarenstein, M, 2009, What is implementation research? Rationale, concepts, and practices, Research on Social Work Practice 19, 5, 491-502

Boak, A, Hamilton, HA, Adlaf, EM, Mann, RE, 2013, Drug use among Ontario students, 19772013: OSDUHS highlights (CAMH Research Document Series No. 37). Toronto, ON: Centre for Addiction and Mental Health.

Capacity Review Committee, 2006, Revitalizing Ontario's public health capacity: The final report of the Capacity Review Committee, www.rnao.ca/sites/rnaoca/files/1._Capacity_Review_Committee_Full_Report_2006.pdf

Canadian Institutes of Health Research [CIHR]: Institute of Population and Public Health \& the Ad Hoc Committee on the Future of Public Health in Canada, 2003, The future of public health in Canada: Developing a public health system for the 21st century, www.publications.gc.ca/collections/collection_2008/cihr-irsc/MR21-108-2003E.pdf

Clark, JP, 2003, How to peer review a qualitative manuscript, in F. Godlee and T. Jefferson (eds) Peer Review in Health Sciences (2nd edition), London: BMJ Books, 219-235

Dixon-Woods, M, Shaw, RL, Agarwal, S, Smith, JA, 2004, The problem of appraising qualitative research, Quality and Safety in Health Care 13, 3, 223-225

Dobbins, M, Robeson, P, Ciliska, D, Hanne, S, Cameron, R, O'Mara, L, DeCorby, K, Mercer, S, 2009, A description of a knowledge broker role implemented as part of a randomized controlled trial evaluating three knowledge translation strategies, Implementation Science 4,23

Eccles, MP, Foy, R, Sales, A, Wensing, M, Mittman, B, 2012, Implementation Science six years on - our evolving scope and common reasons for rejection without review, Implementation Science 7, 71

Ellen, ME, Leon, G, Bouchard, G, Lavis, JN, Ouimet, M, Grimshaw, JM, 2013, What supports do health system organizations have in place to facilitate evidence-informed decisionmaking? A qualitative study, Implementation Science 8, 84

Ellen, ME, Léon, G, Bouchard, G, Ouimet, M, Grimshaw, JM, Lavis, JN, 2014, Barriers, facilitators and views about next steps to implementing supports for evidence-informed decision-making in health systems: a qualitative study, Implementation Science 9, 179 
Elo, S, Kyngäs, H, 2008, The qualitative content analysis process, Advanced Nursing 62, 1, 107115

Francis, D, Turley, R, Thompson, H, Weightman, A, Waters, E, Moore, L, 2015, Supporting the needs of public health decision-makers and review authors in the UK, Journal of Public Health 37, 1, 172-4

Glasgow, RE, Emmons, KM, 2007, How can we increase translation of research into practice? Types of evidence needed, Annual Review of Public Health 28, 413-433

Government of Ontario, 2013, Make No Little Plans Ontario's Public Health Sector Strategic Plan, www.toronto.ca/legdocs/mmis/2013/hl/bgrd/backgroundfile-57698.pdf

Graneheim, UH, Lundman, B, 2004, Qualitative content analysis in nursing research: concepts, procedures and measures to achieve trustworthiness, Nurse Education Today 24, 105-112

Greenhalgh, T, Wieringa, S, 2011, Is it time to drop the 'knowledge translation' metaphor? A critical literature review, Journal of the Royal Society of Medicine 104, 12, 501-09

Grol, R, Grimshaw, J, 2003, From best evidence to best practice: effective implementation of change in patients' care, Lancet 362, 9391, 1225-1230

Hammersley, M, 1997, Qualitative data archiving: some reflections on its prospects and problems, Sociology 31, 1, 131-142

Heaton, J, 2008, Secondary analysis of qualitative data: An overview, Historical Social Research $33,3,33-45$

Higgins, JW, Strange, K, Scarr, J, Pennock, M, Barr, V, Yew, A, Drummond, J, Terpstra, J, 2011, "It's a feel. That's what a lot of our evidence would consist of:" Public health practitioners' perspectives on evidence, Evaluation \& the Health Professions 34, 3, 278296

Hinds, PS, Vogel, RJ, Clarke-Steffen, L, 1997, The possibilities and pitfalls of doing a secondary analysis of a qualitative data set, Qualitative Health Research 7, 3, 408-424

Hsieh, H-F, Shannon, SE, 2005, Three approaches to qualitative content analysis, Qualitative Health Research 15, 9, 1277-1288

Huckel Schneider, C, Campbell, D, Milat, A, Haynes, A, Quinn, E, 2014, What are the key organizational capabilities that facilitate research use in public health policy? Public Health Research \& Practice 25, 1, e2511406

Kamper-Jõrgensen, F, 2000, Knowledge-base, evidence and evaluation in public health, Scandinavian Journal of Public Health 28, 4, 241-243 
Kothari, AR, Bickord, JJ, Edwards, N, Dobbins, MJ, Meyer, M, 2011, Uncovering tacit knowledge: a pilot study to broaden the concept of knowledge in knowledge translation, BMC Health Services Research 11, 198

Kothari, A, Rudman, D, Dobbins, M, Rouse, M, Sibbald, S, Edwards, N, 2012, The use of tacit and explicit knowledge in public health: a qualitative study, Implementation Science 7, 20

Kothari, A, Boyko, JA, Campbell-Davison, A, 2015, An exploratory analysis of the nature of informal knowledge underlying theories of planned action used for public health oriented knowledge translation, BMC Research Notes 8, 424

Kyratsis, Y, Ahmad, R, Hatzaras, K, Iwami, M, Holmes, A, 2014, Making sense of evidence in management decisions: the role of research-based knowledge on innovation adoption and implementation in health care, Health Services and Delivery Research 2, 6

Langley, A, Denis, JL, 2011, Beyond evidence: the micropolitics of improvement, BMJ 20, Suppl 1, i43-i46

LaRocca, R, Yost, J, Dobbins, M, Ciliska, D, Butt, M, 2012, The effectiveness of knowledge translation strategies used in public health: a systematic review, BMC Public Health 12, 751

Lavis, JN, Boyko, JA, Oxman, AD, Lewin, S, Fretheim, A, 2009, SUPPORT Tools for evidenceinformed health Policymaking (STP) 14: Organising and using policy dialogues to support evidence-informed policymaking, Health Research Policy and Systems 7, Suppl $1, \mathrm{~S} 14$

Lavis, JN, Posada, FB, Haines, A, Osei, E, 2004, Use of research to inform public policymaking, Lancet 364, 9445, 1615-1621

Laws, R, King, L, Hardy, LL, Milat, A, Rissel, C, Newson, R, Rychetnik, L, Bauman, AR, 2013, Utilization of a population health survey in policy and practice: a case study, Health Research Policy and Systems 11, 4

Lincoln, YS, Guba, EG, 1985, Naturalistic inquiry, Beverly Hills, CA: Sage

Manuel, DG, Perez, R, Bennett, C, Rosella, L, Taljaard, M, Roberts, M, Sanderson, R, Meltem, T, Tanuseputro, P, Manson, H, 2012, Seven more years: The impact of smoking, alcohol, diet, physical activity and stress on health and life expectancy in Ontario. An ICES/PHO Report, Toronto: Institute for Clinical Evaluative Science and Public Health Ontario

Masood, S, Kothari, A, Regan, S, 2017, The use of research in public health policy: a systematic review, Evidence \& Policy [Under Review]

Mayring, P, 2000, Qualitative content analysis, Forum Qualitative Sozial Forschung/Forum: Qualitative Social Research 1, 2, Art. 20 
Meagher-Stewart, D, Solberg, SM, Warner, G, MacDonald, JA, McPherson, C, Seaman, P, 2012 , Understanding the role of communities of practice in evidence-informed decision making in public health, Qualitative Health Research 22, 6, 723-739

Milat, AJ, King, L, Newson, R, Wolfenden, L, Rissel, C, Bauman, A, Redman, S, 2014, Increasing the scale and adoption of population health interventions: experiences and perspectives of policy makers, practitioners, and researchers, Health Research Policy and Systems 12,18

Ministry of Health and Long-Term Care (MOHLTC), 2014, Public Health Units, www.health.gov.on.ca/en/common/system/services/phu/default.aspx

Ministry of Health and Long-Term Care (MOHLTC), 2015, Ontario Public Health Standards, www.health.gov.on.ca/en/pro/programs/publichealth/oph_standards/

Ministry of Health and Long-Term Care (MOHLTC), 2016, Ontario public health standards 2008. Revised May 2016, www.health.gov.on.ca/en/pro/programs/publichealth/oph_standards/docs/ophs_2008.pdf

Mitton, C, Adair, CE, McKenzie, E, Patten, SB, Waye Perry, B, 2007, Knowledge transfer and exchange: review and synthesis of the literature, Milbank Quarterly 85, 4, 729-768

Morgan, D, 1993, Qualitative content analysis: a guide to paths not taken, Qualitative Health Research 3, 1, 112-121

Naylor, D, Basrur, S, Bergeron, MG, Brunham, R, Butler-Jones, D, Dafoe, G, Ferguson-Paré, M, Lussing, F, McGeer, A, Neufeld, KR, Plummer, F, 2003, Learning from SARS: Renewal of public health in Canada: A report of the National Advisory Committee on SARS and Public Health, www.phac-aspc.gc.ca/publicat/sars-sras/naylor/index-eng.php

Ontario Chronic Disease Prevention Alliance (OCDPA), 2014, Make Ontario the Healthiest Province - Advocacy Toolkit, www.ocdpa.on.ca/sites/default/files/OCDPA_2014_15_ HealthiestProvince_Toolkit.pdf

Orton, L, Lloyd-Williams, F, Taylor-Robinson, D, O'Flaherty, M, Capewell, S, 2011, The use of research evidence in public health decision making processes: systematic review, PloS ONE 6, 7, e21704

Patton, MQ, 1990, Qualitative evaluation and research methods, Beverly Hills, CA: Sage

Perrier, L, Mrklas, K, Lavis, JN, Straus, SE, 2011, Interventions encouraging the use of systematic reviews by health policymakers and managers: a systematic review, Implementation Science 6, 43 
Polit, DF, Hungler, BP, 1999, Nursing Research. Principles and Methods (6th ed.), Philadelphia, New York, Baltimore: Lippincott Company

Pope, C, Ziebland, S, Mays, N, 2000, Qualitative research in health care: analysing qualitative data, $B M J, 320,7227,114-116$

Public Health Services Hamilton, 2008, Ontario Public Health Standards BOH09004 (City Wide) - Information report, www.hamilton.ca/NR/rdonlyres/38C4CFD7-2536-4B7F8A40-D24C3F792BCE/0/Jan26BOH09004OntarioPublicHealthStandards.pdf

Rosella, LC, Wilson, K, Crowcroft, NS, Chu, A, Upshur, R, Willison, D, Deeks, SL, Schwartz, B, Tustin, J, Sider, D, Goel, V, 2013, Pandemic H1N1 in Canada and the use of evidence in developing public health policies - a policy analysis, Social Science \& Medicine 83, 19

Renewal of Public Health Systems (RePHS), 2010, Renewal of public health services in BC and Ontario, www.uvic.ca/research/groups/cphfri/projects/currentprojects/rephs/index.php

Sandelowski, M, 2000, Whatever happened to qualitative description? Research in Nursing \& Health 23, 4, 334-340

Sandelowski, M, 2010, What's in a name? Qualitative description revisited, Research in Nursing \& Health 33, 1, 77-84

Statistics Canada, 2015, Canadian Community Health Survey, 2014, www.statcan.gc.ca/dailyquotidien/150617/dq150617b-eng.htm

Szabo, V, Strang, VR, 1997, Secondary analysis of qualitative data, Advances in Nursing Science 20, 2, 66-74

Thomson, H, 2013, Improving utility of evidence synthesis for healthy public policy: the three Rs (relevance, rigor, and readability [and resources]), American Journal of Public Health $103,8, \mathrm{e} 17-23$

Tracy, SJ, 2010, Qualitative quality: Eight "big tent" criteria for excellent qualitative research, Qualitative Inquiry 16, 10, 837-851

van Kammen, J, de Savigny, D, Sewankambo, N, 2006, Using knowledge brokering to promote evidence-based policy-making: The need for support structures, Bulletin of the World Health Organization 84, 8, 608-612

Wathen, CN, Sibbald, SL, Jack, SM, Macmillan, HL, 2011, Talk, trust, and time: a longitudinal study evaluating knowledge translation and exchange processes for research on violence against women, Implementation Science 6, 102 
Yousefi-Nooraei, R, Dobbins, M, Alexandra, M, 2014, Social and organizational factors affecting implementation of evidence-informed practice in a public health department in Ontario: a network modelling approach, Implementation Science 9, 29

Zardo, P, Collie, A, 2014, Predicting research use in a public health policy environment: results of a logistic regression analysis, Implementation Science 9, 142 